\title{
1 Submarine salt dissolution in the Santos Basin, offshore
} Brazil

${ }^{1}$ Basins Research Group (BRG), Department of Earth Science \& Engineering, Imperial College, London, SW7 2BP, United Kingdom

$8 \quad{ }^{2}$ Department of Earth Science, University of Bergen, Allégaten 41, 5007 Bergen, Norway

${ }^{3}$ WesternGeco Schlumberger, Schlumberger House, Gatwick Airport, Horley, West

§Corresponding author email: c.rodriguez11@imperial.ac.uk

\section{Abstract}

14 Salt dissolution occurs when evaporite-dominated rocks come into contact with $\mathrm{NaCl}$ -

15 undersaturated fluids. Salt dissolution can positivity and negatively impact hydrocarbon

16 and mineral exploration, seismic imaging, drilling, and structural restorations in salt-

17 bearing sedimentary basins. However, due to typically poor seismic imaging and a lack

18 of borehole data, few studies have analysed the detailed morphology of salt dissolution-

19 related features (i.e., salt karst) and how this relates to intrasalt stratigraphic

20 heterogeneity, and associated deformation within post-salt overburden. Here we

21 integrate high-quality 3D seismic reflection data, a regional 2D seismic reflection line,

22 and borehole data from the Santos Basin, offshore Brazil to characterise salt dissolution-

23 related features at the crest of buried salt diapirs. 
24 We recognise: (i) flat $\left(<10^{\circ}\right)$, halite-dominated crests mainly characterised by up to 100

$25 \mathrm{~m}$ tall, sub-circular mounds, likely comprising insoluble evaporite; (ii) rugose, evaporite-

26 interbedded crests mainly characterised by up to $100 \mathrm{~m}$ deep, oval-to-circular sinkholes

27 above more soluble evaporite units; and (iii) up to $60 \mathrm{~m}$ tall breccia pipes, capped by

28 collapse-related sinkholes within the overburden above the flat and rugose crests.

29 Reverse-basin modelling suggests salt dissolution occurred in a fully submarine

30 environment in water depths of $1900 \mathrm{~m}( \pm 100 \mathrm{~m})$, which, in combination with seismic-

31 stratigraphic-relationships in post-salt strata, suggests dissolution occurred due to (i)

32 superjacent $\mathrm{NaCl}$-undersaturated seawater which penetrated exposed, thin (up to $60 \mathrm{~m}$ )

33 overburden; and (ii) lateral updip migration of formation fluids from flanking submarine

34 channels and lobes. We are therefore able to demonstrate a direct link between the

35 intrasalt stratigraphic heterogeneity, and the style of salt karst, and related deformation

36 in post-salt sedimentary overburden, providing evidence for widespread dissolution of

37 salt in a fully submarine environment.

39 1. Introduction

40 Salt (i.e. rocks comprised of soluble minerals that precipitate from the evaporation of

41 brines) is typically dissolved when it comes into contact with $\mathrm{NaCl}$-undersaturated

42 waters. Salt composition varies hence its solubility; i.e., the most soluble and weaker

43 evaporite minerals are the bittern salts ( $\mathrm{K}$ and $\mathrm{Mg}$ salts, e.g., carnallite, tachyhydrite)

44 followed by halite $(\mathrm{NaCl})$, whereas the least soluble are anhydrite and gypsum (e.g.;

45 Warren, 2006). Hence, when salt dissolution occurs, the more-soluble evaporites 
46 (bitterns and halite) are dissolved first, resulting in the body becoming relatively

47 enriched in anhydrite and other insoluble intrasalt residue. Prolonged contact with

48 undersaturated fluids may lead to rehydration of anhydrite and the formation of

49 gypsum, a process particularly common in caprock formed at the top of diapirs (e.g.

50 Jackson et al. 1990; Hovorka, 2000; Warren, 2006). In addition, anaerobic microbial

51 activity within caprocks can lead to the deposition of thick calcium carbonate- and

52 sulphite-rich units (e.g.; Kyle and Posey, 1991; Jackson and Hudec, 2017).

53 Subaerial dissolution of salt has been extensively studied, indicating this process

54 typically results in: (i) discordant geometrical relationships between remaining salt and

55 overburden, (ii) the formation of a residual caprock or diapiric solution breccias, (iii) the

56 development of salt karst features, such as sinkholes, grooves, caves, and residual

57 mounds; and (iv) overburden deformation (e.g.; Jackson et al., 1990; Warren, 1997;

58 Cartwright et al., 2001; Abelson et al., 2006; Warren, 2006; Bruthans et al., 2009; Hudec

59 et al., 2011; Frumkin, 2013; Gutiérrez and Lizaga, 2016; Jackson and Hudec, 2017). Salt

60 karst identified in Iran resemble those related to subterranean karstic dissolution of

61 calcium carbonate, which have been imaged by seismic data and studied due to the

62 importance of carbonate rocks as hydrocarbon reservoirs (e.g. Evans et al., 1994;

63 Vahrenkamp et al., 2004; Sullivan et al. 2006; Zeng et al., 2011; Burberry et al., 2016).

64 However, salt dissolution is not restricted to the subaerial realm, occurring also in

65 submarine settings (e.g., Bertoni and Cartwright, 2005; Talbot and Augustin, 2016). For

66 example, in the Orca Basin, Gulf of Mexico a salt body is currently exposed at the

67 seabed and is currently being dissolved by NaCl-undersaturated seawater, producing

68 brines that flow downslope into an enclosed submarine brine lake (Shokes et al., 1977; 
69 Tompkins and Shephard, 1979; Pilcher and Blumstein, 2007). Large-scale, likely

70 submarine dissolution of salt has also been inferred for flat- and rugose-topped diapirs

71 imaged in seismic reflection data in the Barents Sea (e.g. Koyi et al. 1995) and in the

72 Netherlands (e.g. Duin, 2001), although the detailed geometry of salt karst and

73 overburden deformation features in both these examples remain unknown.

74 Identifying salt dissolution and characterising the range of related structural styles has a

75 range of important implications and applications. First, the less-soluble residual

76 evaporite rocks at the crest of dissolved salt structures (i.e, caprock) are the source of

77 economic minerals and have the potential to become reservoir rocks (e.g., Posey and

78 Kyle, 1988; Kyle, 1999). Salt dissolution and related faulting may also generate local

79 accommodation in diapir overburden, potentially promoting reservoir deposition and

80 trap development (e.g., Ge and Jackson, 1998; Cartwright et al., 2001; Hudec et al.,

81 2011; Jackson et al., 2010). In addition, dissolution and related deformation can

82 generate mega-pores and diagenetic alterations, thus reducing the sealing properties of

83 the salt and its overburden, and making it difficult to drill through salt (e.g., Walles,

84 1993; Black, 1997; Vahrenkamp et al., 2004; Willson and Fredrich, 2005; Jackson and

85 Hudec, 2017). Accurate seismic imaging in salt-bearing sedimentary basins requires a

86 good understanding of caprock stratigraphy and associated seismic velocities variations

87 at the crest and lateral margins of salt structures (e.g., Jackson and Lewis, 2012; Jones

88 and Davison, 2014). Finally, the amount of salt dissolved from the geological record is

89 often unknown, thereby challenging our ability to structurally restore salt-bearing

90 sedimentary basins (e.g, Koyi et al. 1995; Cartwright et al., 2001; Rowan and Ratliff,

91 2012). 
92 Despite being widespread, and although clearly significant in terms of its impact on

93 resource exploitation, surprisingly few studies have used 3D seismic reflection data to

94 investigate the processes and products of large-scale salt-related dissolution (e.g.;

95 Bertoni and Cartwright, 2005; Pilcher and Blumstein, 2007; Jackson and Lewis, 2012;

96 Burberry et al., 2016; George et al., 2017). This is perhaps surprising given that, despite

97 being unable to resolve sub-decametre structural or stratigraphic details, 3D seismic

98 reflection data do permit relatively detailed characterisation of salt karst-related

99 morphologies and associated overburden deformation over very large areas and for

100 several structures. When coupled with borehole data, seismic expression can be

101 correlated to salt and overburden, which can in turn be related to observed dissolution

102 structural style. A subsurface-based approach, drawing on 3D seismic reflection and

103 borehole data can thus compliment other, principally 1D (e.g. borehole) to quasi-3D (i.e.

104 field) approaches.

105 The aims of our study are to; (i) characterise the style of intra- and supra-salt,

106 dissolution-related deformation; (ii) relate deformation style to intrasalt stratigraphic

107 heterogeneity, (iii) understand the mechanisms driving salt dissolution; and (iv)

108 determine whether dissolution was submarine or subaerial, and to critically discuss

109 what this means for the regional geodynamic evolution of the study area. To achieve

110 these aims we integrate high-quality 3D seismic reflection, 2D seismic and borehole

111 data from the Santos Basin, offshore Brazil, focusing on six, very well-imaged diapirs.

112 This is an ideal location to characterise salt karst and overburden morphology, given the

113 relatively shallow burial depth $(<1000 \mathrm{~m})$ of the studied diapirs and resultant excellent 
114 seismic reflection imaging. Furthermore, borehole data and highly reflective intra-salt

115 layers allow salt karst style to be related to intrasalt stratigraphic heterogeneity.

\section{2. Geological setting}

118 The Santos Basin is located in eastern offshore Brazil and originated as a result of the 119 opening of the South Atlantic Ocean between east South America and West Africa (Fig.

120 1). During the Barremian, non-marine to shallow marine sediments were deposited

121 within rift basins formed due to continental stretching (Fig. 2; e.g., Demercian, 1996;

122 M eisling et al., 2001; Gomes et al., 2002; Moreira et al., 2007). An initially isolated and

123 irregular rift-related valley was intermittently flooded by seawater in the Aptian, with

124 subsequent dessication events leading to deposition of a regionally extensive, up $2.5 \mathrm{~km}$

125 thick, evaporite-dominated sequence (i.e., Ariri Formation; e.g., Szatmari 2000; Dias 126 2004; Davison 2007; Karner and Gambôa, 2007; Davison et al., 2012; Rodriguez et al. (a)

127 in press). Subsequent Albian widening and deepening of the proto-south Atlantic Ocean

128 promoted deposition of a shallow-marine carbonate platform in proximal areas and

129 marls in distal areas (Fig. 2; Moreira et al., 2007). Fully marine conditions became 130 established in the Late Cretaceous, following drowning of the Albian carbonate

131 platform. Subsequent uplift and south-eastwards tilting of this segment of the Brazilian 132 margin drove south-eastwards progradation of a thick, clastic-dominated wedge (Fig. 2,

133 e.g. Modica and Brush, 2004; M oreira et al., 2007).

134 From the Turonian to the Paleocene, deep-water systems were initially deposited within 135 a large, salt-controlled, intra-slope depocenter called the 'Albian Gap', before spilling 
136 further south-eastwards into numerous smaller minibasins (e.g. Rodriguez et al.(b) in

137 press). Subsequent onshore uplift and diversion of the Paraiba do Sul river to the NE

138 during the Eocene resulted in relatively limited sediment supply to the Santos Basin,

139 with deposition dominated by suspension settling of very fine-grained clastics and

140 carbonates, and emplacement of shelf- and salt-sourced mass transport complexes

141 (MTCs) (e.g., Cobbold et al., 2001; Modica and Brush, 2004; Guerra and Underhill, 2012;

142 Rodriguez et al.(b) in press). Apart a few, albeit large, shelf-sourced MTCs (e.g., Jackson

143 2011; Rodriguez et al.(b), in press), post-Eocene deposition in the central deepwater

144 Santos Basin dominated by very fine-grained sediment (Fig. 2; M odica and Brush, 2004;

145 Moreira et al., 2007; Guerra and Underhill, 2012).

\section{3. Dataset}

148 We use a high-quality 3D time-migrated seismic reflection volume (provided by CGG), a

149 2D post-stack depth-migrated seismic that intersects the 3D volume (provided by

150 WesternGeco), and data from eight publicly available boreholes (Fig. 1b). Borehole data

151 are sparse across the study area, containing only cutting-derived lithology information,

152 and formation markers for the presalt, the intrasalt and postsalt sequences. Two of the

153 boreholes contain a comprehensive set of electrical logs for the intrasalt (eg. GR,

154 Neutron, Density and P-Sonic), and these allow us to tie seismic and borehole data, and

155 to assign lithology information to the mapped intervals (Fig. 2a).

156 The 2D depth seismic profile is c. $350 \mathrm{~km}$ long and has a record length of $16 \mathrm{~km}$,

157 providing a good quality regional image along the central deep-water Santos Basin (Fig. 
158 2b). The high-quality 3D seismic reflection volume covers an area of $20,122 \mathrm{~km}^{2}$ and 159 contains trace data from the sea level down to 5.5 seconds two-way time (TWT). The 3D 160 dataset has a vertical sample rate of $4 \mathrm{~ms}$, inline spacing (east-west) of $18.75 \mathrm{~m}$ and 161 crossline spacing (north-south) of $25 \mathrm{~m}$. The stratigraphic units of interest (i.e.; unit 3, 162 unit 4 and the intrasalt within the crests of salt walls; Fig. 2a) lie between 3.2-3.6 s TWT 163 interval of the 3D seismic data. The dominant frequency varies with depth but it is C. 40

$164 \mathrm{~Hz}$ in unit 3 and unit 4 and c. $37 \mathrm{~Hz}$ in the intrasalt units near the crest of the salt walls.

165 The vertical seismic resolution within these units is estimated to be $12 \mathrm{~m}$ and $30 \mathrm{~m}$, 166 based on average interval velocities of $1900 \mathrm{~m} \mathrm{~s}^{-1}$ for the shallowly buried overburden 167 and $4500 \mathrm{~m} \mathrm{~s}^{-1}$ for the salt. The interval velocities used for the stratigraphic units of 168 interest are averages, based on checkshot data from boreholes 532A, 723C and 709 (Fig.

169 1b). Regional seismic profiles from 2D and 3D data are displayed with SEG normal 170 polarity, where a downward increase in acoustic impedance is represented by a positive 171 reflection event (black) and a downward decrease in acoustic impedance is represented 172 by a negative reflection event (red). Local seismic profiles from 3D data, which illustrate 173 detailed salt karst features, are also displayed with SEG normal polarity although, in 174 these images, a positive reflection event is red and a negative reflection event is blue.

\section{4. Methods}

177 We mapped eight key regional horizons in depth along the 2D seismic profile (Fig. 2b).

178 We mapped these horizons, excluding Basement, but including three additional intrasalt

179 horizons imaged near the diapir crests, in the 3D seismic volume in TWT (top A1, top A2 
180 and top A3; Figs. 2a; 3a). A synthetic seismogram provides a tie between lithology and 181 seismic expression for the intrasalt stratigraphy and the Top Salt (boreholes 709 and

182 532A; Figs. 3a, 3b; see also Jackson et al. 2015b and Rodriguez et al.(a) in press). For the 183 post-salt stratigraphy, ages and lithology were assigned to seismic horizons based on

184 regional studies and major lithological breaks or unconformities identified in borehole 185 723C (Fig. 3c; Modica and Brush, 2004; Contreras et al.; 2010; Guerra and Underhill, 186 2012). For the detailed analysis at the crests of salt diapirs, high-resolution (i.e.; seismic 187 grid spacing of $18.75 \mathrm{~m} \times 25 \mathrm{~m}$ ) structural maps were generated for the Top Salt and 188 overburden horizons.

189 We use several seismic attributes to aid our analysis: (1) amplitude contrast - this 190 involves calculation of amplitude derivatives between neighbouring traces 191 (Schlumberger, 2012), and we use it here mainly in map-view to highlight structural 192 discontinuities along top salt; (2) chaos - this recognises disorganized seismic traces 193 within a 3D window (Randen and Sønneland, 2005), and we use it here mainly in 194 map/plan-view? to investigate and map intra-salt facies variations subcropping top salt; 195 and (3) sweetness - this integrates amplitude strength (envelope) and instantaneous 196 frequency (Hart, 2008), and we use it here mainly to highlight cross-sectional variations 197 in seismic facies along the crest of salt walls, and between and within key intrasalt 198 intervals.

199 We conduct reverse-basin modelling or 'backstripping' of a 2D regional seismic profile 200 to estimate the paleo-water depths at the time of which dissolution likely occurred (i.e.

201 Paleocene; see below) (for general discussion of approach and application in rift basins, 202 see Roberts et al., 2009 and Bell et al., 2014). More specifically, this technique allows us 
203 to assess if dissolution occurred in the subaerial or submarine realm. We justify our

204 application of an overburden-focused, reverse-basin modelling technique (rather than a

205 full kinematic restoration of the salt) for the following reasons: (i) salt movement was

206 likely minimal during and after salt dissolution (i.e., Palaeocene); i.e. we are not

207 attempting to reconstruct the main phases of salt-related deformation, which largely

208 occurred prior to dissolution, during the Albian to Maastrichtian (e.g.; Modica and

209 Brush, 2004; Jackson et al., 2014, 2015; Rodriguez et al.(b) in press); and (ii) only very

210 limited thickness variations occur within post-salt sedimentary overburden capping flat-

211 topped diapirs, again suggesting limited large-scale, syn- to post-dissolution salt

212 movement (Fig. 2c). Reverse reverse-basin modelling technique involves removing: (1)

213 the effect of sediment load and (2) the effect of post-rift thermal subsidence of each of

214 the sedimentary layers in the overburden until the horizon of interest is reached. The

215 removal of each sedimentary layer results in the decompaction of the remaining layers

216 allowing the basin geometry at the time at which the horizon of interest was deposited

217 to be resolved.

218 A summary of reverse-basin modelling input parameters is shown in Table 1. Lithology

219 information is mainly based on the final well reports available and based on the

220 integration with seismic stratigraphy and seismic attribute analysis by Rodriguez et

221 al.(b), in press (Figs. 2c, 3c; Table 1). A key input parameter in modelling of this type is

222 the effective elastic thickness $\left(T_{e}\right)$, a parameter expressing the strength of the 223 lithosphere (Watts, 1992). In this study, we use a $T_{e}$ of $5 \mathrm{~km}$, which is representative of

224 the Santos Basin's thinned and thus relatively weak crust, above which loads are 
226 et al.; 2012). Another key input parameter is the beta stretching factor ( $\beta$ ), for which we

227 have used a range of values constrained by the 'minimum' and 'maximum' profiles

228 presented by Scotchman et al. (2006). The minimum profile presented by Scotchman et

229 al. (2006) assumes that base salt subsidence from Aptian to the Holocene is due to both

230 syn-rift and post-rift subsidence. Conversely, the maximum profile was calculated 231 assuming that base salt subsidence over the same period occurred due to post-rift 232 thermal subsidence only (Scotchman et al., 2006, 2010).

\section{5. Salt-related structural domains}

235 Before we describe the detailed, dissolution-related morphologies at the crests of salt

236 structures, we first describe the broad salt-related structural domains present within

237 the Santos Basin, with a focus on the external shape and internal structure of salt walls.

238 Our 2D seismic profile illustrates how salt-related deformation in the Santos Basin varies

239 from NW to SE. Overall, we identify six structural domains (Fig. 2 b, c), i.e.; (i) an 240 upslope, extensional domain, characterised by salt rollers and landward- and 241 basinward-dipping, thin-skinned listric faults; (ii) the Albian Gap, a large, intraslope 242 depocenter, which is bound on its downdip side by a large diapir, and which trapped 243 large amounts of sediment during the Cretaceous to Eocene (e.g., Jackson et al. 244 2015a); (iii) a minibasin domain, characterised by thick ( $>2.5 \mathrm{~km}$ deep) minibasins 245 overlying thin or welded salt and bounded by up to $20 \mathrm{~km}$-wide salt walls; (iv) the 'Inner 246 São Paulo Fold Belt' (ISPFB; sensu Jackson et al. 2015b), which is defined as a zone of

247 salt-cored folds and predominantly landward-dipping thrusts; (v) the São Paulo Plateau 
248 (SPP), which is bound on its eastern margin by the 'Outer High', and which defines a

249 broad structural high characterised by a landward-dipping base salt. The SPP is capped

250 by a highly-reflective, up to $2.5 \mathrm{~km}$ thick salt sequence and numerous minibasins; and

251 (vi) a deep basin lying east of the Outer High.

252 The Top Salt structural map generated from our 3D seismic interpretation illustrates the 253 present salt-related deformation occurring in the study area (Fig. 4a). We focus on 254 diapirs in the minibasin domain, the ISPFB and the SPP. Based on distinctly different 255 plan-view trends, external morphologies and sizes, we identify two main types of salt 256 diapir. The first type occurs in the minibasin domain and the ISPFB, trend broadly E or N, 257 and are characterised by broadly rounded but, in detailed, somewhat rugose crests (R258 west; R-central or 'Liam'; see Jackson et al. (2015 b); and R-east; Figs. 4 a, b). These 259 diapirs are up $10 \mathrm{~km}$ wide and $4 \mathrm{~km}$ tall. The second type of diapir occurs in the more 260 distal part of the SPP, trend broadly $\mathrm{N}$ or NE, and are characterised by strikingly sub261 horizontal (<10॰ dip) crests (F-west, F-central, and F-east; Fig. 4 a, c). Note that F-central 262 and F-east correspond to Jimi and Freddie of Jackson et al. (2015b). These diapirs are 263 wider (up to $15 \mathrm{~km}$ ) but not as tall (up to $2.5 \mathrm{~km}$ ) as the rounded diapirs (Figs. $4 \mathrm{~b}$ and 264 4c).

265 Despite their relatively simple external morphologies, many diapirs display considerably 266 greater internal structural complexity (e.g., Davison et al., 2012; Fiduk and Rowan, 2012; 267 Jackson et al., 2014a, 2015b). Of particular interest for this study is the contrast in 268 intrasalt structural style between the flat-topped diapirs, the upper parts of which are 269 invariably dominated by poorly-reflective, intra-salt sheets (Fig. 4c, e.g., Jackson et al. $2702014 a, 2015 b)$, and the rounded salt diapirs, which may locally contain intra-salt sheets 
271 (e.g. R-east in Fig. 4b), but which may also contain reverse shear zones and internal

272 anticlines (R-west and R-central in Fig 4b, see also Jackson et al., 2015b). This structural

273 and associated compositional variability is important when we later consider the style

274 of salt dissolution and its relationship with subcropping intrasalt stratigraphy (see 275 below).

277 6. Intrasalt and postsalt stratigraphy

278 Seismic data show that the top of the Aptian salt is characterised by a high-amplitude

279 and broadly continuous seismic event, reflecting the large acoustic impedance contrast 280 between the relatively high-velocity salt and lower velocity, non-evaporitic overburden

281 (Figs. 3b, 4b, c). Boreholes penetrating the salt indicate Top Salt correlates with a 12-56 $282 \mathrm{~m}$ thick anhydrite (Fig. 3b). Along the crests of rounded, rugose diapirs, Top Salt exhibits 283 a discordant stratigraphic relationship with highly reflective, anhydrite-halite-carnallite284 interbedded, A2 and low-to-moderate-amplitude, relatively halite-rich A3 (Table 2; Fig. 285 4b). Conversely, Top Salt overlies poorly reflective, halite-rich, A1-allochtonous sheets 286 at the crests of flat-topped diapirs (Table 3; Figs. 4c; see also Jackson et al.; 2015b).

287 Seismic data show the postsalt sequence in the distal ISPFB and SPP is characterised by 288 low-to-moderate amplitude, continuous seismic reflections, except for Unit 3, which is 289 defined by unconformity-bound wedges composed of moderate-to-high-amplitude, 290 discontinuous to chaotic seismic facies (i.e., Maastrichtian-to-Palaeocene seismic unit 291 on Fig. 4c; see also Rodriguez et al.(b) in press). Above the crests of diapirs, Unit 3 is 292 dominated by low-to-moderate amplitude reflections, although its seismic expression 
293 varies between salt diapirs; i.e., conformable continuous sheets, disrupted sheets with 294 apparent downlap, mounded, rotated and chaotic (SF1-SF7; Tables 2 and 3). Boreholes

295 that penetrate the ISPFB and the SPP indicate that the post-salt succession is mostly 296 dominated by fine-grained lithologies, predominantly mudstones and marls (boreholes $297532 \mathrm{~A}, 723 \mathrm{C}, 709,594$, Fig. 1b). However, a notable exception occurs on the eastern 298 flank of a distal minibasin in the SPP, where Unit 1 and Unit 3 are characterised by 299 interbedded mudstone, siltstone and sandstone (borehole 723C, Fig. 4c). The salt diapir 300 crests of interest are not penetrated by boreholes. Rodriguez et al.(b), (in press) show

301 that Unit 3 contains sandstone-rich channel-levee and lobes complexes, some of which 302 are capped by mudstone-dominated Mass Transport Complexes (MTCs). The channels 303 and lobes within Unit 3 onlap onto and dip away from some of the salt walls in the 304 study area (Fig. 4c; Rodriguez et al.(b), in press).

306 7. Seismic expression of salt karst

307 Having described the external morphology of the diapir crests, and the stratigraphy and 308 seismic expression of the salt and its overburden, we here use high-resolution top salt 309 structural maps and seismic attributes to describe salt karst features. We also describe 310 the spatial relationship between salt karst features and: (i) underlying variations in 311 intra-salt lithology; and (ii) overburden deformation patterns (Tables 2 and 3). 
$31450 \mathrm{~ms}$ TWT deep (c. 100 metres deep) by c. 50 to $500 \mathrm{~m}$ diameter, circular to oval315 shaped depressions occur along Top Salt (Figs. 5 and 6). The depressions are 'U'- or ' $V$ '316 shaped in cross-section, with their margins dipping $60^{\circ}-90^{\circ}$ (Figs. $5 \mathrm{~d}$, e). The bases of 317 the depressions are characterised by lower sweetness attribute values (Fig. 5e) and 318 higher chaos attribute values (Fig. 6e) than otherwise observed along Top Salt, 319 suggesting lateral variations in the composition and structure. Depressions are isolated 320 or clustered (Figs. 5b, 6b). Depressions are best developed along diapirs characterised 321 by rounded crests, typically underlying mounded-to-chaotic overburden (SF6 and SF7), 322 and overlying halite-rich A3 and truncated, dipping, heterogeneous A2 (Table 2; Figs. 5d, $3236 d)$.

324 Based on their seismic expression, geometry, scale and occurrence atop a salt-rich unit, 325 we interpret these features as sinkholes or dolines that formed due to dissolution at the 326 diapir crests (cf. Spain; Elorza and Santolalla, 1998; Gutiérrez et al., 2008; Galve et al., 327 2009; United States; Ege, 1984; Johnson, 2005, 2008). Furthermore, our analysis 328 suggests that variability in top salt subcrop, related to intrasalt structural and 329 stratigraphic variability (R-west, R-central and R-east), led to preferential dissolution 330 and development of sinkholes above the more soluble, halite-rich A3, and dipping, more 331 heterogeneous layers of A2 (Figs. 5d-e, $6 \mathrm{~d}$-e). We speculate that sinkholes preferentially 332 develop within the more soluble, halite- and carnallite-rich layers within A2. Irrespective 333 of the precise underlying lithological control on sinkhole formation, it is clear that their 334 development led to deformation of immediately overlying overburden strata (e.g., SF6 335 and SF7; Table 2). 


\section{$337 \quad 7.2$ Residual mounds}

$33850 \mathrm{~ms}$, TWT (c. 100 metres deep) by $50 \mathrm{~m}$ to $500 \mathrm{~m}$ in diameter, sub-circular, elongate 339 and irregular mounds occur along the Top Salt (Figs. 7-9). The local positive-relief 340 features are defined by steeply-dipping (c. $\left.70^{\circ}-90^{\circ}\right)$ walls and smooth or rugose tops

341 (Figs. 7d, 8c and 9e). We note that, in contrast to the negative-relief sinkholes described 342 above, these features are characterised by high sweetness attribute values along the 343 top salt (Figs. 7e, 8d). In addition, these mounds are bounded by high chaos attribute 344 values, representing discontinuities along the top salt and in the overburden (Fig. 8d).

345 These mounds are most evident where they appear in clusters below semi-continuous 346 to disrupted strata (SF1, SF2 and SF4) and above poorly-reflective, A1-allocthonous347 sheets (e.g., F-east, F-west and F-central; Table 3; Figs. 7b, 8b). In addition, some 348 isolated mounds are also found along the rugose crests, overlying poorly-reflective A3 349 and highly-reflective A2 and underlying mounded-to-chaotic overburden strata (e.g, 350 SF5, R-central; Fig. 9b, e).

351 Based on their seismic expression, geometry, scale and occurrence atop a salt-rich unit, 352 we interpret these features as salt dissolution-related karst mounds formed by the 353 insoluble residuum left after dissolution of halite-rich, A1 sheets (e.g., Posey and Kyle, 354 1988; Warren, 1997; Kyle and Posey, 1991; Hovorka, 2000; Jaworska and Novak, 2013; 355 Jackson and Hudec, 2017). Geometrically similar, gypsum-dominated karst hills or 356 mounds, formed due to near-surface dissolution in the subaerial realm, have been 357 described from other sedimentary basins (e.g., Stafford et al., 2008, Chiesi et al., 2010). 358 We also suggest that the more isolated mounds rising above the crests of rounded- 
359 topped diapirs represent the remains of A4 and A3 evaporites dissolved from the cores 360 of intrasalt anticlines (Fig. 9).

\section{$362 \quad 7.3$ Breccia pipes}

$36360 \mathrm{~ms}$ (TWT) (c. 60 metres) tall by c. 30 metres wide, parallel to sub-parallel, linear pipes 364 cross-cut the overburden strata (Fig. 10). The pipes are defined by downward-deflected 365 v-shaped depressions which die-out upwards (Fig. 10b). The lowest downward flexure 366 of the pipes defines apparent downlaps on the Top Salt (SF2, Table 3). The uppermost 367 downward flexure capping the pipes define subcircular to oval-shaped (up to $200 \mathrm{~m}$ 368 long, $100 \mathrm{~m}$ wide) sinkholes contained within linear (up to $2 \mathrm{~km}$ long, $200 \mathrm{~m}$ wide) 369 depressions (Fig. 11c). The edges of the linear depressions are defined by high 370 amplitude contrast attribute in plan-form (Fig. 10a). The pipes are characterised by high

371 chaos and relatively low sweetness attribute values across the overburden strata (Figs.

$37210 \mathrm{c}, \mathrm{d}$ ). These vertical discontinuities are best developed in the strata above F-central 373 and in less extent above F-east, F-west and R-west (e.g., Figs. 8d, 10 and 11). The 374 sinkholes capping the pipes are locally onlapped by a relatively more continuous seismic 375 event of Paleocene-age (Fig. 11 d). Furthermore, we note that the pipes within the 376 overburden are aligned at depth with steps and seismic facies variations along the Top 377 Salt (e.g., Figs. 8c-e, 10d).

378 Based on their seismic expression, geometry, scale and occurrence in strata overlying 379 salt-rich units, we infer these features are breccia pipes or chimneys formed due to 380 collapse above dissolving diapirs. Geometrically and seismically similar, pipe-like 
381 features, also flanked by downward deflected reflections, are documented in seismic 382 reflection data from other carbonate- and evaporite-bearing basins (e.g. Hardage et al., 383 1996; Bertoni and Cartwright, 2005; Burberry et al., 2016). We infer pipes in the Santos

384 Basin are likely filled with insoluble, likely non-evaporitic sedimentary material that 385 caved in from the overburden. We can approximately constrain the timing of pipe collapse based on the stratigraphic level at which related deformation terminates, with this approaching suggesting Late-Maastrichtian-to-Paleocene deformation (Fig. 11d). 388 The approximate timing of dissolution-related collapse is also constrained by the horizon onlapping the uppermost sinkholes, which cap the breccia pipes (e.g. Fig. 11d).

\section{Subaerial or submarine salt dissolution?}

393 We have provided compelling evidence for salt dissolution at the crest of several diapirs

394 in central deep-water Santos Basin. Furthermore, the spatial relationship between

395 overburden deformation (Tables 2 and 3) and underlying salt karst features (section 7)

396 suggest dissolution was subterranean, and occurred in the Paleocene, under an up to c.

$39760 \mathrm{~m}$ thick overburden of fine-grained strata (e.g., Figs. 8, 10 and 11). However, it is still 398 uncertain if the entire succession was submerged or exposed when dissolution 399 occurred.

400 Dissolution typically occurs in the subaerial realm (e.g.; the Zechstein salt in the North

401 Sea; Clark et al., 1998; Cartwright et al., 2001 and Texas salt diapirs; Jackson and Seni, 402 1984, Hudec and Jackson, 2011). If this was the case for the Santos Basin, this would 
403 have major implications for our understanding of the post-rift subsidence profile of the

404 basin, and eustatic sea-level variations during the early Paleogene. More specifically,

405 this would indicate that the crests of the salt diapirs and a thin (c. $60 \mathrm{~m}$ ) overburden

406 were subaerially exposed in the Paleocene. However, numerous observations suggest

407 that, in the Santos Basin, dissolution occurred in a fully submarine setting. More

408 specifically, the stratigraphic context and analysis presented by previous studies (e.g.,

409 Modica and Brush, 2004; Moreira et al., 2007; Contreras et al., 2010; de M elo Garcia et

410 al., 2012; Guerra and Underhill, 2012; Rodriguez et al (b)., in press) provide enough

411 evidence that the Santos Basin was characterised by deep waters at least since the

412 Cenomanian. We here attempt to provide a more precise estimate of water depth by

413 reconstructing the basin to the Paleocene.

414 Our backstripped profiles are shown on Figures $12 \mathrm{~d}$-g; these satisfy the crustal and

415 sediment key input parameters for the central deep-water Santos Basin discussed in the

416 Methods section and shown in Table 1. We present two restorations, based on the

417 minimum (Fig. 12b) and maximum (Fig. 12c) $\beta$ estimate profiles provided by Scotchman

418 et al. $(2006,2010)$. To estimate the paleowater depths at the top of Unit 3, the effect of

419 sediment load and post-rift thermal subsidence during Unit4 and Unit 5 deposition are

420 removed (Fig. 12d-g). The removal of Unit 4 and Unit 5 results in the decompaction of

421 the remaining layers and illustrates the basin geometry at the end of deposition of Unit

4223 (Figs. $12 \mathrm{f}, \mathrm{g}$ ). The restoration to the top Unit 3 (i.e. Paleocene; Fig. 3c) predicts that,

423 regardless of the $\beta$ factor, the diapirs were submarine when dissolution occurred, with

424 their crests lying in waters depths of 1800-2000 m (R-west and F-west, Figs. $12 \mathrm{f}, \mathrm{g}$ ). 


\section{9. Discussion}

428 We have provided compelling evidence for fully submarine dissolution of salt at the

429 crest of several diapirs in central deep-water Santos Basin, offshore Brazil. Furthermore,

430 we demonstrate that intrasalt stratigraphic heterogeneity along the salt wall crests

431 controlled salt karst morphology and the associated style of deformation developed

432 within the overburden (section 7). We now discuss the mechanisms that may have

433 triggered salt dissolution, and implications of our findings.

\subsection{Mechanism of salt dissolution}

436 Salt dissolution occurs by: (i) descending $\mathrm{NaCl}$-undersaturated fluids, such as

437 freshwater, coming into contact with salt (superjacent dissolution; e.g., Johnson, 1997;

438 Cartwright et al., 2001; Zarei et al.; 2012); (ii) fluids moving laterally through carrier

439 beds in contact with salt (lateral dissolution; e.g.; Ege, 1984; Johnson, 1997; Warren,

4401997 ); or (iii) ascending $\mathrm{NaCl}$-undersaturated fluids, such as connate brines sourced

441 from sub-salt strata, coming into contact with structurally higher salt (subjacent

442 dissolution; e.g., Bertoni and Cartwright. 2005; Jackson and Lewis, 2012; Burberry et al., 443 2016)

444 Considering these mechanisms in the context of the Santos Basin example, we suggest 445 that subjacent dissolution, with fluids sourced from subsalt stratigraphy, is unlikely 446 considering the likely impermeable nature of the very tall (>1000 ms, TWT; >2000 m), 
447 evaporite-dominated diapirs and the fine-grained-dominated, flanking minibasins (Fig. 4

448 b, c). Although clastics and carbonates are present within the salt, it is in only small 449 proportions and they are likely left in welds (e.g.; Jackson et al. 2014b). Therefore, we 450 infer that dissolution of the crests occurred either by superjacent $\mathrm{NaCl}$-undersaturated

451 seawater or by fluids that migrated laterally from carrier beds directly in contact with 452 the salt.

453 We therefore propose that superjacent dissolution is the only feasible mechanism for 454 driving widespread salt dissolution in the central deep-water Santos Basin during the 455 Paleocene, and in a fully submarine setting. Similar to that occurring in the Orca Basin, 456 northern Gulf of Mexico (Pilcher and Blumstein, 2007), NaCl-undersaturated seawater 457 would have penetrated the very fine-grained, but unlithified and thus highly permeable 458 overburden, driving dissolution of diapir crests. We suggest that subsequent 459 overburden deformation via fracturing, driven by underlying salt depletion, increased 460 permeability and facilitated the further ingress of $\mathrm{NaCl}$-undersaturated seawater, 461 driving to more salt dissolution (Fig. 13a).

462 Considering the Paleocene age of salt dissolution, and the composition and geometry of 463 the post-salt sedimentary overburden (section 9; Figs. 13), we suggest that lateral 464 dissolution, by the migration of fluids from sandstone-rich channels directly in contact 465 with the salt, may also have contributed, locally, to salt dissolution (Fig. 13b). More 466 specifically, we infer that formation fluids may have flowed from the minibasin flanks 467 towards the diapirs crests via sandstone-rich, deepwater turbidites (Fig. 13b). 468 Furthermore, we propose that this mechanism likely promoted the dissolution of the Fcentral and F-west salt walls, which are both flanked by deep-water channels and lobes. 
470 For example, we interpret that formation fluids within the sandstone-rich channels

471 onlapping the crest of F-central became in contact with the A1-halite-rich crests and led

472 to depletion, subsidence and the formation of salt karst atop the crest. We further

473 propose three likely mechanisms that occur isolated or in conjunction, triggering the

474 dewatering of the submarine channels and lobes and the migration of fluids towards

475 the crest: i) initial compaction of the sand-rich submarine channels and lobes (cf. West

476 Africa, Pilcher and Argent, 2007); (ii) coeval salt movement which caused rotation of the

477 channels and levees during deposition (see Rodriguez et al. (b), in press); or (iii) a

478 regional basin-scale event associated to the deposition of mass transport complexes

479 (MTCs) in the Palaeocene and leading to the escape of overpressure fluids.

480 This dissolution mechanism could also explain the variations in the magnitude and style

481 of dissolution between the crests of flat-topped salt walls. For example, we observe that

482 F-west seem to have dissolved more relative to F-east given the larger number of

483 thicker and widespread karst mounds forming the highly-reflective caprock (compare

484 Fig.7 with 8). Related to this, we note that submarine channels and lobes within Unit 3

485 occur on both sides of the highly-dissolved crest of F-west (Rodriguez et al. b; in press).

486 Moreover, F-central shows more depletion of the evaporite-dominate crest adjacent to

487 the flanking submarine channel (Fig. 11). Conversely, submarine channels are not 488 observed at seismic scale next to F-east; suggesting that superjacent dissolution by

$489 \mathrm{NaCl}$-undersaturated seawater may have caused the relatively lower magnitude 490 dissolution observed at its crest. 
$493 \quad 9.2$ Implication of salt dissolution for petroleum systems development

494 Salt may represent a seal or a reservoir, and salt-related deformation may generate

495 traps. A key challenge when understanding reservoir compartment into salt is 496 characterising the size, continuity, connectivity of collape-related features, largely due 497 to poor sesmic imaging and sparse wells. We here show that salt dissolution can 498 significantly influence the structure of overburden strata (section 7). In this study, we 499 illustrate a variety of reflection configurations within strata above dissolved salt walls, 500 which are strongly dependent of the underlying intrasalt stratigraphy, the timing of 501 deposition relative to dissolution and the magnitude of underlying salt-related 502 dissolution (Tables 2 and 3). For example, we show that the dissolution of evaporites503 interbedded salt crests can result in the truncation of the intrasalt stratigraphy and the 504 formation, above, of residual less-soluble caprock that can sometimes preserve the 505 dipping of underlying intrasalt units (Table 3; Fig. 13). The complex reflection 506 configurations and the composition of the overburden can be highly variable comprising 507 a combination of less-soluble residual evaporites combined with sediments collapse 508 from the overburden during subterranean salt depletion (Fig. 13c).

\section{10. Conclusions}

510 The integration of 2D and 3D seismic reflection and borehole data has revealed

511 evidence of submarine salt dissolution in the Santos Basin, offshore Brazil:

512 1. Seismic stratigraphy and seismic attribute analysis illustrate salt karst features at the 513 crests of salt diapirs consisting of: (i) up to $100 \mathrm{~m}$ thick, sub-circular, residual 514 mounds rising above nearly horizontal (<10 $)$ Top Salt; (ii) up to 100 m deep, oval-to- 
515 circular, dissolution sinkholes below the main level of the Top Salt; and (iii) up to 60 $516 \mathrm{~m}$ tall breccia pipes capped by collapse sinkholes within the overburden. Styles of 517 dissolution identified suggest a direct link between the salt karst morphologies and 518 the intrasalt stratigraphic heterogeneity along the top salt.

519 2. Seismic-stratigraphic-relationships in post-salt strata indicate several deformation 520 patterns within the overburden; from local disruption of conformable sheets, 521 rotation and apparent downlap, mounds and highly chaotic. The magnitude of 522 deformation within the overburden is controlled by the magnitude of dissolution of 523 the underlying evaporite-dominated crests; thus, indicating subterranean salt 524 dissolution.

525 3. Reverse-basin modelling indicates that salt dissolution occurred in a fully submarine 526 environment in water depths of $1900 \mathrm{~m}( \pm 100 \mathrm{~m})$.

527 4. Widespread dissolution occurred due to $\mathrm{NaCl}$ undersaturated seawater during 528 partial salt diapir exposure (under an up $60 \mathrm{~m}$ thick, fine-grained dominated 529 overburden) at the seabed; and locally, due to (ii) dissolution by formation fluids 530 migrating from Late-Maastrichtian-to-Paleocene submarine channels and lobes 531 directly in contact with the salt-dominated crests.

532 5. Results presented in this study has direct implications for reservoir characterisation 533 and sealing capacity of the crests of salt diapirs and its overburden.

\section{11. Acknowledgments}

536 We would like to thank CGG for providing access to the 3D seismic data and for granting 537 permission to publish the results of this study. We also thank Statoil and ANP Brazil for 
538 providing access to the borehole data. Schlumberger WesternGeco is also gratefully 539 acknowledged for providing 2D seismic regional data, partial funding and support of this 540 work.

541

\section{$542 \quad 12 . \quad$ Figure captions}

543 FIGURE 1: (a) Eastern Brazil salt-dominated sedimentary basins highlighting the location 544 of the Santos Basin, offshore Brazil; (b) Study area in the central deep-water Santos 545 Basin. Location of 2D seismic profile, 3D seismic reflection and borehole data available 546 for the study.

547 FIGURE 2: (a) Seismic stratigraphic framework; key intrasalt stratigraphic intervals A1548 A4 for this and previous studies (Jackson et al., 2014, 2015; Rodriguez et al.(a) in press). 549 B1, B2 and B3 refer to competent layers or 'beams' defined by high amplitude 550 continuous reflections. D1, D2 and D3 refer to ductile detachment zones defined by 551 acoustically transparent, poorly continuous reflections (Fiduk and Rowan, 2012). (b) 2D 552 depth seismic profile illustrating salt-related structural domains in the Santos Basin. (c) 553 Geoseismic profile with interpreted seismic units.

554 FIGURE 3: (a) Borehole (709) and seismic expression for the intrasalt stratigraphy. A1555 A4 intrasalt key stratigraphic intervals are defined by vertical variations in seismic facies 556 and the integration with borehole data. Intrasalt lithology was identified based on the 557 typical well log response for evaporites for a combination of wireline logs; i.e., density 558 (RHOB), sonic (DT), neutron porosity (NPHI) and gamma-ray (GR) (see also. Jackson et al., 2015; Rodriguez et al., in press); (b) Borehole (532A) and seismic expression of the 560 Top Salt in a structurally-low and relatively undeformed area; (c) Borehole (723C) and 
561 seismic expression of the post-salt sedimentary overburden. Key post-salt seismic units

562 are defined based on vertical variations in seismic facies and the integration with

563 borehole data.

564 FIGURE 4: (a) Top salt structural map with locations of salt walls of interest; (b) Seismic

565 section across salt diapirs with rounded and rugose crests; (c) Seismic section across salt 566 diapirs with flat crests.

567 FIGURE 5: Seismic expression of salt dissolution-related sinkholes: (a) R-west top salt

568 structural map; (b) Salt karst along Top Salt and intrasalt stratigraphy subcropping the R-

569 west salt diapir; (c) Amplitude contrast attribute map for R-west Top Salt highlighting

570 the sinkholes along Top Salt, see Figure 5a for location; (d) Seismic section along the

571 crest of R-east illustrating the geometry of sinkholes (indicated by white arrows) and

572 their relationship to halite-rich A3 intrasalt unit. Location is shown on Figure $5 \mathrm{c}$; (e)

573 Sweetness attribute of the seismic section on (d).

574 FIGURE 6: Seismic expression of salt dissolution-related sinkholes: (a) R-east top salt 575 structural map; (b) Salt karst along Top Salt and Intrasalt stratigraphy subcropping R576 east salt diapir; (c) Amplitude contrast attribute map for R-east Top Salt highlighting the 577 sinkholes along Top Salt, see Figure 6a for location; (d) Seismic section along the crest of 578 R-east illustrating the geometry of sinkholes (indicated by white arrows) and their 579 relationship to dipping-A2 intrasalt stratigraphy. Location is shown on Figure $6 \mathrm{c}$; (e) 580 Chaos attribute of the seismic section on Figure $6 \mathrm{~d}$ highlighting the sinkholes along the 581 Top Salt.

582 FIGURE 7: Seismic expression of residual mounds: (a) F-east top salt structural map; (b) 583 Intrasalt unit subcropping F-east salt diapir; (c) Amplitude contrast attribute map for F- 
584 east Top Salt highlighting residual mounds above the nearly-horizontal Top Salt; (d) 585 Seismic section along the crest of F-east illustrating residual mounds above the main top 586 salt level (mounds are indicated by white arrows). See Figure 7c for location; (e) 587 Sweetness attribute for section on Figure 7d highlighting potential facies variations 588 along the Top Salt.

589 FIGURE 8: Seismic expression of residual mounds: (a) F-west Top Salt structural map; (b) 590 Salt karst along Top Salt and intrasalt stratigraphy subcropping F-west Top Salt; (c) 591 Seismic section along the crest of F-west illustrating residual mounds defined by highly592 reflective packages along the Top Salt (mounds are indicated by white arrows). See 593 location on (a) and (b); (d) Chaos attribute for the seismic section on (c) highlighting the 594 discontinuities along the Top Salt and within the overburden; (e) Sweetness attribute 595 for section on (a) illustrating the facies variations along Top Salt and within the mounds. 596 FIGURE 9: Seismic expression of residual mounds: (a) R-central Top Salt structural map; 597 (b) Salt karst morphology and intrasalt stratigraphy subcropping R-central Top Salt; (c) 598 Zoom into Top Salt structural map highlighting the location of the residual mounds; (d) 599 Amplitude contrast map of 8 c; (d) Seismic section across mounds on R-Central salt 600 diapir illustrating remnant mounds after A4 and A3 dissolution. See (c) and (d) for 601 location.

602 FIGURE 10: Seismic expression of breccia pipes or chimneys within the overburden: (a) 603 Amplitude contrast seismic attribute time slice highlighting the edges of the breccia 604 pipes. See location on Figure 11a; (b) Seismic section accross the crest of F-central and 605 overburden strata. Breccia Pipes are indicated with white arrows; (c) Chaos seismic 606 attribute for the section on Figure 10b highlighting the breccias cross-cutting the 
607 overburden strata; (d) Sweetness seismic attribute for the section on Figure 10b. Some 608 of the breccia pipes correlate with facies variations along the Top Salt.

609 FIGURE 11: (a) F-central Top Salt structural map; (b) Salt karst morphology and intrasalt 610 stratigraphy along the crest of F-central; (c) Structural map for the seismic horizon 611 within the overburden (blue on (d)) highlighting the collapse associated to dissolution of 612 the underlaying halite-rich crest and the top of a channel flanking the salt wall; (d)

613 Seismic section across F-central and the flanking minibasin illustrating the onlap of the 614 channel and discontinuities within the overburden.

615 FIGURE 12: (a) Input model used for basin restoration based on the interpretation of 2D 616 depth seismic profile (Figure 2b). See Key on Figure 2a; (b) Minimum Beta Stretching 617 Factor along the 2D seismic profile (after Scotchman et al., 2006); (c) Maximum Beta 618 Stretching Factor along the 2D seismic profile (after Scotchman et al., 2006); (d) Basin 619 restoration to the mid-Oligocene (28 $\mathrm{Ma}$ ) based on the minimum Beta Stretching Factor 620 profile; (e) Basin restoration to the mid-Oligocene (28 $\mathrm{Ma}$ ) based on the maximum Beta 621 Stretching Factor profile; (f) Basin restoration to the Paleocene (60 Ma) based on the 622 minimum Beta Stretching Factor profile; (f) Basin restoration to the Paleocene (60 M a) 623 based on the maximum Beta Stretching Factor profile

624 FIGURE 13: Mechanisms and styles of submarine salt dissolution: (a) Superjacent 625 dissolution by $\mathrm{NaCl}$-undersaturated seawater penetrating the very fine-grained, 626 unlithified overburden during exposure at the seafloor; (b) Dissolution due to fluids 627 migrating from carrier beds directly in contact with the salt; (c) Residual Solution breccia 628 formed by the preferential depletion of the evaporite-dominated crests and collapse of 629 the overburden. 


\section{13. Table captions}

633 Table 1: Post-salt sediment key input parameters for the basin restoration based on

634 seismic interpretation and well reports available.

635 Table 2: Overburden seismic expression and thickness variations above dissolved rugose 636 crests.

637 Table 3: Overburden seismic expression and thickness variations above dissolved flat 638 crests.

639

\section{14. References}

641 Abelson, M., Yechieli, Y., Crouvi, O., Baer, G., Wachs, D., Bein, A. and Shtivelman, V., 642 2006. Evolution of the Dead Sea sinkholes. Geological Society of America Special Papers, 643 401, pp.241-253.

644 Bell, R.E., Jackson, C., Elliott, G.M., Gawthorpe, R.L., Sharp, I.R. and Michelsen, L., 2014. 645 Insights into the development of major rift-related unconformities from geologically 646 constrained subsidence modelling: Halten Terrace, offshore mid Norway. Basin 647 Research, 26(1), pp.203-224. 
648 Bertoni, C. and Cartwright, J.A., 2005. 3D seismic analysis of circular evaporite 649 dissolution structures, Eastern M editerranean. Journal of the Geological Society, 162(6), $650 \quad$ pp.909-926.

651 Black, T.J., 1997. Evaporite karst of northern lower Michigan. Carbonates and 652 Evaporites, 12(1), p.81.

653 Burberry, C.M., Jackson, C.A.L. and Chandler, S.R., 2016. Seismic reflection imaging of 654 karst in the Persian Gulf: Implications for the characterization of carbonate reservoirs. 655 AAPG Bulletin, 100(10), pp.1561-1584.

656 Bruthans, J., M. Filippi, N. Asadi, M. Zare, S. Šlechta, and Z. Churáčková, 2009, Surficial 657 deposits on salt diapirs (Zagros Mountains and Persian Gulf Platform, Iran): 658 Characterization, evolution, erosion and the influence on landscape 659 morphology. Geomorphology, 107(3), pp: 195-209.

660 Cartwright, J., Stewart, S. and Clark, J., 2001. Salt dissolution and salt-related 661 deformation of the Forth Approaches Basin, UK North Sea. Marine and Petroleum 662 Geology, 18(6), pp.757-778.

663 Chiesi, M., J. De Waele, and P. Forti, 2010, Origin and evolution of a salty 664 gypsum/anhydrite karst spring: the case of Poiano (Northern Apennines, Italy). 665 Hydrogeology Journal, 18(5), pp. 1111-1124.

666 Cobbold, P.R., K.E. M eisling, and V.S. Mount, 2001, Reactivation of an Obliquely Rifted 667 Margin, Campos and Santos Basins, Southeastern Brazil: AAPG Bulletin, v. 85, pp. 19256681944. 
669 Davison, I., 2007, Geology and tectonics of the South Atlantic Brazilian salt basins: 670 Geological Society, London, Special Publications, v. 272, pp. 345-359.

671 Davison, I., L. Anderson, and P. Nuttall, 2012, Salt deposition, loading and gravity

672 drainage in the Campos and Santos salt basins: Geological Society, London, Special 673 Publications, v. 363, p. 159-174.

674 de Melo Garcia, S.F., Letouzey, J., Rudkiewicz, J.L., Danderfer Filho, A. and de Lamotte, 675 D.F., 2012. Structural modeling based on sequential restoration of gravitational salt 676 deformation in the Santos Basin (Brazil). Marine and Petroleum Geology, 35(1), pp.337677353.

678 De Waele, J., Plan, L. and Audra, P., 2009. Recent developments in surface and 679 subsurface karst geomorphology: an introduction.

680 Demercian, L.S., 1996, A halocinese na evolução do Sul da Bacia de Santos do Aptiano 681 ao Cretáceo Superior, MS thesis., p. 201.

682 Dias, J.L. 2004, Tectônica, estratigrafia e sedimentação no Andar Aptiano da margem 683 leste brasileira: Boletim de Geociências da PETROBRAS, v. 13, pp. 7-25.

684 Duin, E., 2001. A detailed 3D seismic interpretation of a salt dome and its caprock, a 685 case study in the northeastern Netherlands. In SEG Technical Program Expanded 686 Abstracts 2001 (pp. 670-673). Society of Exploration Geophysicists.

687 Ege, J.R., 1984. Formation of solution-subsidence sinkholes above salt beds (No. 897). 688 US Geological Survey,. 
689 Elorza, M.G. and F.G. Santolalla, 1998, Geomorphology of the Tertiary gypsum 690 formations in the Ebro Depression (Spain). Geoderma, 87(1), pp. 1-29.

691 Evans, M.W., S.W. Snyder, and A.C. Hine, 1994, High-resolution seismic expression of 692 karst evolution within the upper Floridan Aquifer system: Crooked Lake, Polk County, 693 Florida. Journal of Sedimentary Research, 64(2).

694 Fiduk, J. C., and M. G. Rowan, 2012, Analysis of folding and deformation within layered 695 evaporites in Blocks BM-S-8 \& -9, Santos Basin, Brazil: Geological Society, London, 696 Special Publications, v. 363, p. 471-487.

697 Friedman, G.M., 1997. Dissolution-collapse breccias and paleokarst resulting from 698 dissolution of evaporite rocks, especially sulfates. Carbonates and Evaporites, 12(1), 699 pp.53-63.

700 Frumkin, A., 1994. Hydrology and denudation rates of halite karst. Journal of Hydrology, $701 \quad$ 162(1-2), pp.171-189.

702 Frumkin, A., 2013. Salt karst. Treatise on geomorphology, 6, pp.407-424.

703 Galve, J. P., F. Gutiérrez, J. Remondo, J. Bonachea, P. Lucha, and A. Cendrero, 2009, 704 Evaluating and comparing methods of sinkhole susceptibility mapping in the Ebro Valley 705 evaporite karst (NE Spain). Geomorphology, 111(3), pp: 160-172.

706 Ge, H. and Jackson, M.P., 1998. Physical modeling of structures formed by salt 707 withdrawal: Implications for deformation caused by salt dissolution. AAPG bulletin, 708 82(2), pp.228-250. 
709 George, M., O.K. Olakunle, J.S. Emil, and P. Abrahamson, 2017, Seismic interpretation

710 and characterization of anhydrite caprocks in the Tromsø Basin, SW Barents Sea. Marine

711 Geology, 390, pp. 36-50.

712 Gomes, P.O., J. Parry, and W. Martins, 2002, The outer high of the Santos Basin,

713 southern São Paulo Plateau, Brazil: tectonic setting, relation to volcanic events and

714 some comments on hydrocarbon potential: AAPG Hedberg Conference,'Hydrocarbon

715 Habitat of Volcanic Rifted Passive Margins, pp. 8-11.

716 Guerra, M.C.M., and J.R. Underhill, 2012, Role of halokinesis in controlling structural

717 styles and sediment dispersal in the Santos Basin, offshore Brazil: Geological Society,

718 London, Special Publications, v. 363, pp. 175-206.

719 Gutiérrez, F., J. Guerrero, and P. Lucha, 2008, A genetic classification of sinkholes

720 illustrated from evaporite paleokarst exposures in Spain. Environmental Geology, 53(5),

721 pp. 993-1006.

722 Gutiérrez, F. and Lizaga, l., 2016. Sinkholes, collapse structures and large landslides in an

723 active salt dome submerged by a reservoir: The unique case of the Ambal ridge in the

724 Karun River, Zagros M ountains, Iran. Geomorphology, 254, pp.88-103.

725 Hardage, B.A., D.L. Carr, D.E. Lancaster, J.L. Simmons Jr, R.Y. Elphick, V.M. Pendleton,

726 and R.A. Johns, 1996, 3-D seismic evidence of the effects of carbonate karst collapse on

727 overlying clastic stratigraphy and reservoir compartmentalization. Geophysics, 61(5), 728 pp. 1336-1350.

729 Hart, B., 2008, Stratigraphically significant attributes: The Leading Edge, v. 27, pp. 320730324 
731 Hovorka, S.D., 2000, Understanding the Process of Salt Dissolution and Subsidence.

732 Solution M ining Research Institute Proceedings.

733 Hudec, M.R., Jackson, M.P., Vendeville, B.C., Schultz-Ela, D.D. and Dooley, T.P., 2011.

734 The salt mine: A digital atlas of salt tectonics.

735 Jackson, C.A., 2011. Three-dimensional seismic analysis of megaclast deformation within

736 a mass transport deposit; implications for debris flow kinematics. Geology, 39(3), 737 pp.203-206.

738 Jackson, C.A., Kane, K.E. and Larsen, E., 2010. Structural evolution of minibasins on the 739 Utsira High, northern North Sea; implications for Jurassic sediment dispersal and 740 reservoir distribution. Petroleum Geoscience, 16(2), pp.105-120.

741 Jackson, C.A.L. and Lewis, M.M., 2012. Origin of an anhydrite sheath encircling a salt 742 diapir and implications for the seismic imaging of steep-sided salt structures, Egersund 743 Basin, Northern North Sea. Journal of the Geological Society, 169(5), pp.593-599.

744 Jackson, C. A.-L., M. P. Jackson, and M. R. Hudec, 2015a, Understanding the kinematics 745 of salt-bearing passive margins: A critical test of competing hypotheses for the origin of 746 the Albian Gap, Santos Basin, offshore Brazil: Geological Society of America Bulletin, v. $747 \quad 127$, p. 1730-1751.

748 Jackson, C. A.-L., M. P. A. Jackson, M. R. Hudec, and C. Rodriguez, 2014, Internal 749 structure, kinematics, and growth of a salt wall: Insights from 3-D seismic data: Geology, 750 v. 42, p. $307-310$. 
751 Jackson, C. A. L., M. P. A. Jackson, M. R. Hudec, and C. R. Rodriguez, 2015b, Enigmatic

752 structures within salt walls of the Santos Basin-Part 1: Geometry and kinematics from

753 3D seismic reflection and well data: Journal of Structural Geology, v. 75, p. 135-162.

754 Jackson, M.P.A. and M.R. Hudec, 2017. Salt Tectonics: Principles and Practice.

755 Cambridge University Press. pp. 424-428.

756 Jackson, M.P.A. and Seni, S.J., 1984. The domes of east Texas, pp. 163-179.

757 Jackson, M.P.A., Cornelius, R.R., Craig, C.H., Gansser, A., Stöcklin, J. and Talbot, C.J., 758 1990. Salt diapirs of the Great Kavir, central Iran. Geological Society of America 759 Memoirs, 177, pp.1-150.

760 Jackson, M.P. and Hudec, M.R., 2016. Salt Tectonics: Principles and Practice. Cambridge 761 University Press.

762 Jaworska, J. and Nowak, M., 2013. Anhydrites from gypsum cap-rock of Zechstein salt 763 diapirs. Geology, Geophysics and Environment, 39(3), pp.233-250.

764 Johnson, K.S., 1997. Evaporite karst in the United States. Carbonates and Evaporites, 765 12(1), pp.2-14.

766 Johnson, K.S., 2005. Subsidence hazards due to evaporite dissolution in the United 767 States. Environ Geol, 48 (3), pp. 395-409.

768 Johnson, K.S., 2008. Evaporite-karst problems and studies in the USA. Environmental 769 Geology, 53(5), pp. 937-943.

770 Jones, I.F. and Davison, I., 2014. Seismic imaging in and around salt bodies. 771 Interpretation, 2(4), pp.SL1-SL20. 
772 Karner, G.D. and L.A.P. Gambôa, 2007, Timing and origin of the South Atlantic pre-salt

773 sag basins and their capping evaporites: Geological Society, London, Special

774 Publications, v. 285, pp. 15-35.

775 Koyi, H., Talbot, C.J. and Torudbakken, B.O., 1995. Analogue models of salt diapirs and 776 seismic interpretation in the Nordkapp Basin, Norway. Petroleum geoscience, 1(2), 777 pp.185-192.

778 Koyi, H., 1998. The shaping of salt diapirs. Journal of Structural Geology, 20(4), pp.321779338.

780 Kyle, J.R., 1999. Industrial-M ineral Resources Associated with Salt Domes, Gulf of 781 Mexico Basin, USA. In Proceedings of the 34th Forum on the Geology of Industrial 782 Minerals: Oklahoma Geological Survey, Circular (Vol. 102, pp. 161-178).

783 Kyle, J.R. and H.H. Posey, 1991, Halokinesis, cap rock development, and salt dome 784 mineral resources. Developments in sedimentology, 50, pp. 413-474.

785 Loucks, R.G., 1999. Paleocave carbonate reservoirs: origins, burial-depth modifications, 786 spatial complexity, and reservoir implications. AAPG bulletin, 83(11), pp.1795-1834.

787 Machel, H.G., Borrero, M.L., Dembicki, E., Huebscher, H., Ping, L. and Zhao, Y., 2012. The 788 Grosmont: the world's largest unconventional oil reservoir hosted in carbonate rocks. 789 Geological Society, London, Special Publications, 370(1), pp.49-81.

790 Meisling, K.E., P.R. Cobbold, and V.S. Mount, 2001, Segmentation of an Obliquely Rifted 791 Margin, Campos and Santos Basins, Southeastern Brazil: AAPG Bulletin, v. 85, pp. 19037921924. 
793 Modica, C. J., and E. R. Brush, 2004, Postrift sequence stratigraphy, paleogeography,

794 and fill history of the deep-water Santos Basin, offshore southeast Brazil: AAPG Bulletin, 795 v. 88, p. 923-945.

796 Moreira, J. L. P., C. Madeira, J. A. Gil, and M. A. P. Machado, 2007, Bacia de Santos: 797 Bulletin Geociencias Petrobras, v. 15, p. 531-549.

798 Pilcher, R.S. and Blumstein, R.D., 2007. Brine volume and salt dissolution rates in Orca 799 Basin, northeast Gulf of M exico. AAPG bulletin, 91(6), pp.823-833.

800 Posey, H.H. and Kyle, J.R., 1988. Fluid-rock interactions in the salt dome environment: 801 an introduction and review. Chemical Geology, 74(1-2), pp.1-24.

802 Randen, T. and Sønneland, L., 2005. Atlas of 3D seismic attributes. In Mathematical 803 Methods and Modelling in Hydrocarbon Exploration and Production (pp. 23-46). 804 Springer Berlin Heidelberg.

805 Roberts, A.M., R.I. Corfield, N.J. Kusznir, S.J., Matthews, E.K. Hansen, and R.J. Hooper, 806 2009. Mapping palaeostructure and palaeobathymetry along the Norwegian Atlantic 807 continental margin: Møre and Vøring basins. Petroleum Geoscience, 15(1), pp. 27-43.

808 Rodriguez, C.R., C.A.L. Jackson, R.E. Bell, A. Rotevatn, and M. Francis, In press (b). 809 Minibasin development and reservoir deposition on a salt-influenced deep-water slope: 810 Santos Basin, offshore Brazil. Accepted by the AAPG Bulletin.

811 Rodriguez, C.R., C.A.L. Jackson, A. Rotevatn, R.E. Bell, and M. Francis, In press (a). 812 Stratigraphy of salt giants: new insights from the Santos Basin, offshore Brazil. Accepted 813 by Geosphere. 
814 Rowan, M.G. and Ratliff, R.A., 2012. Cross-section restoration of salt-related 815 deformation: Best practices and potential pitfalls. Journal of Structural Geology, 41, 816 pp.24-37.

817 Schlumberger, 2012, Interpreter's guide to seismic attribuite, $4^{\text {th }}$ edition, pp. 112-114.

818 Scotchman, I.C., Gilchrist, G., Kusznir, N.J., Roberts, A.M. and Fletcher, R., 2010. The

819 breakup of the South Atlantic Ocean: formation of failed spreading axes and blocks of

820 thinned continental crust in the Santos Basin, Brazil and its consequences for petroleum

821 system development. In Geological Society, London, Petroleum Geology Conference 822 series (Vol. 7, No. 1, pp. 855-866). Geological Society of London.

823 Scotchman, I.C., G. Marais-Gilchrist, F.G.D. Souza, F.F. Chaves, L.A. Atterton, A.M. 824 Roberts, and N. J. Kusznir, 2006, A failed sea-floor-spreading centre, Santos Basin, Brazil:

825 Rio Oil \& Gas Expo and Conference, Rio de Janeiro.

826 Scott, E., Peel, F., Taylor, C., Bryant, W. and Bean, D., 2001. Deep water Gulf of M exico

827 sea floor features revealed through 3D seismic. In Offshore Technology Conference.

828 Offshore Technology Conference.

829 Shokes, R.F., Trabant, P.K., Presley, B.J. and Reid, D.F., 1977. Anoxic, hypersaline basin in 830 the northern Gulf of M exico. Science, 196(4297), pp.1443-1446.

831 Stafford, K.W., R. Nance, L. Rosales-Lagarde, and P.J. Boston, 2008, Epigene and 832 hypogene karst manifestations of the Castile Formation: Eddy County, New Mexico and 833 Culberson County, Texas, USA. 
834 Sullivan, E.C., M arfurt, K.J., Lacazette, A. and Ammerman, M., 2006. Application of new

835 seismic attributes to collapse chimneys in the Fort Worth Basin. Geophysics, 71(4), 836 pp.B111-B119.

837 Szatmari, P., 2000, AAPG Memoir 73, Chapter 6: Habitat of Petroleum Along the South 838 Atlantic M argins, pp. 69-75.

839 Talbot, C. and Augustin, N., 2016. Submarine Salt Karst Terrains. AlM S Geosciences, $8402(2)$, pp.182-200.

841 Tompkins, R.E. and Shephard, L.E., 1979. Orca Basin: Depositional processes, 842 geotechnical properties and clay mineralogy of Holocene sediments within an anoxic 843 hypersaline basin, northwest Gulf of Mexico. Marine Geology, 33(3-4), pp.221-238.

844 Vahrenkamp, V. C., F. David, P. Duijndam, M. Newall, and P. Crevello, 2004. Growth 845 architecture, faulting, and karstification of a middle Miocene carbonate platform, 846 Luconia Province, offshore Sarawak, Malaysia, in Seismic imaging of carbonate 847 reservoirs and systems: AAPG M emoir 81, p. 329- 350.

848 Walles, F.E., 1993. Tectonic and diagenetically induced seal failure within the south849 western Great Bahamas Bank. M arine and petroleum geology, 10(1), pp.14-28.

850 Warren, J.K., 1997. Evaporites, brines and base metals: Fluids, flow and 'the evaporite 851 that was'. Australian Journal of Earth Sciences, 44(2), pp.149-183.

852 Warren, J.K., 2006. Evaporites: sediments, resources and hydrocarbons. Springer 853 Science $\&$ Business Media. 
854 Watts, A.B., 1992, The effective elastic thickness of the lithosphere and the evolution of 855 foreland basins. Basin Research, 4(3-4), pp. 169-178.

856 Willson, S.M. and J.T. Fredrich, 2005, January. Geomechanics considerations for 857 through-and near-salt well design. In SPE Annual Technical Conference and Exhibition. 858 Society of Petroleum Engineers.pp 1-17.

859 Zarei, M., Raeisi, E. and Talbot, C.J., 2012. Karst development on a mobile substrate: 860 Konarsiah salt extrusion, Iran. Geological Magazine, 149(03), pp.412-422.

861 Zeng, H., Wang, G., Janson, X., Loucks, R., Xia, Y., Xu, L. and Yuan, B., 2011. 862 Characterizing seismic bright spots in deeply buried, Ordovician paleokarst strata, 863 Central Tabei uplift, Tarim Basin, Western China. Geophysics, 76(4), pp.B127-B137. 
(a)

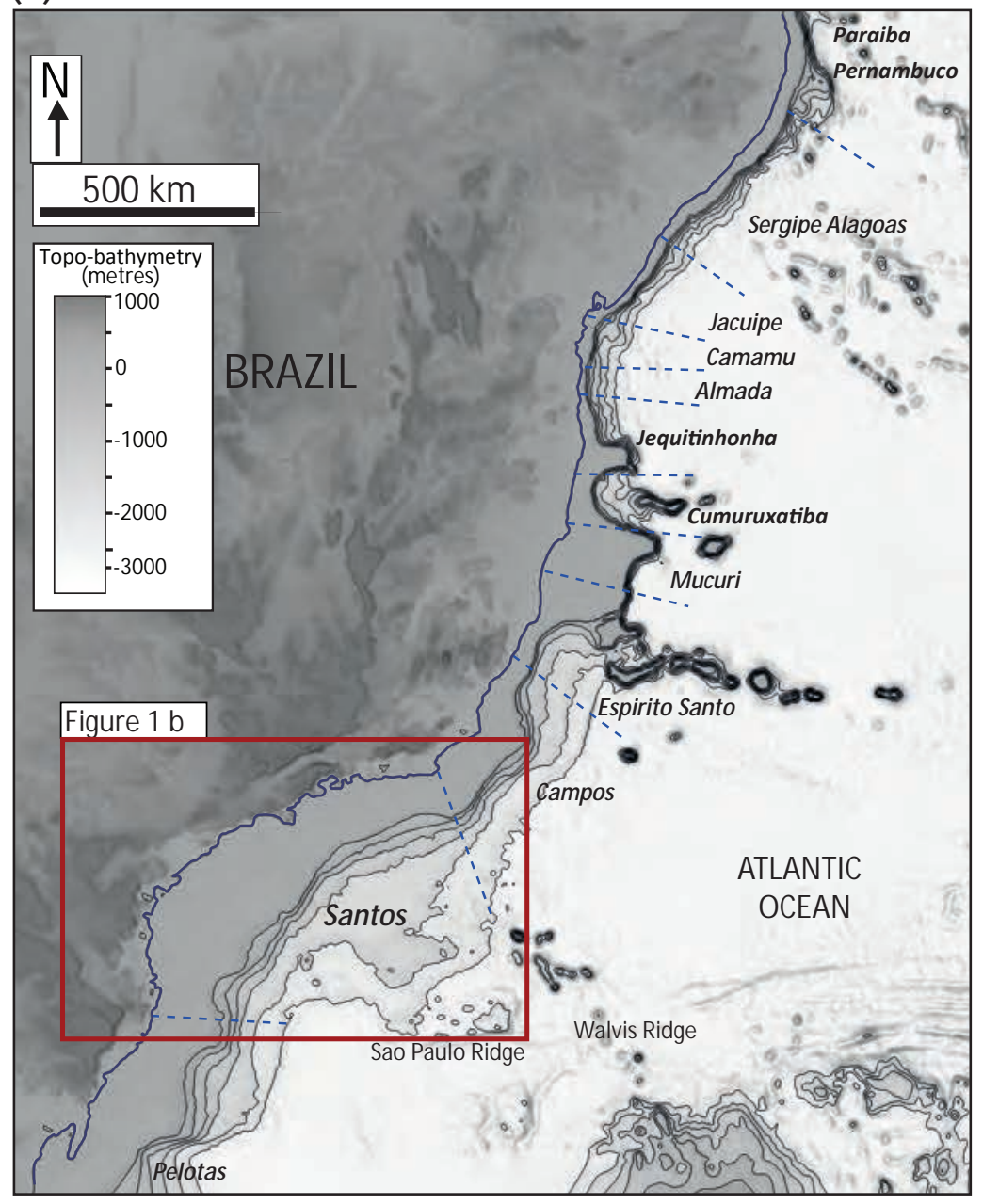

(b)

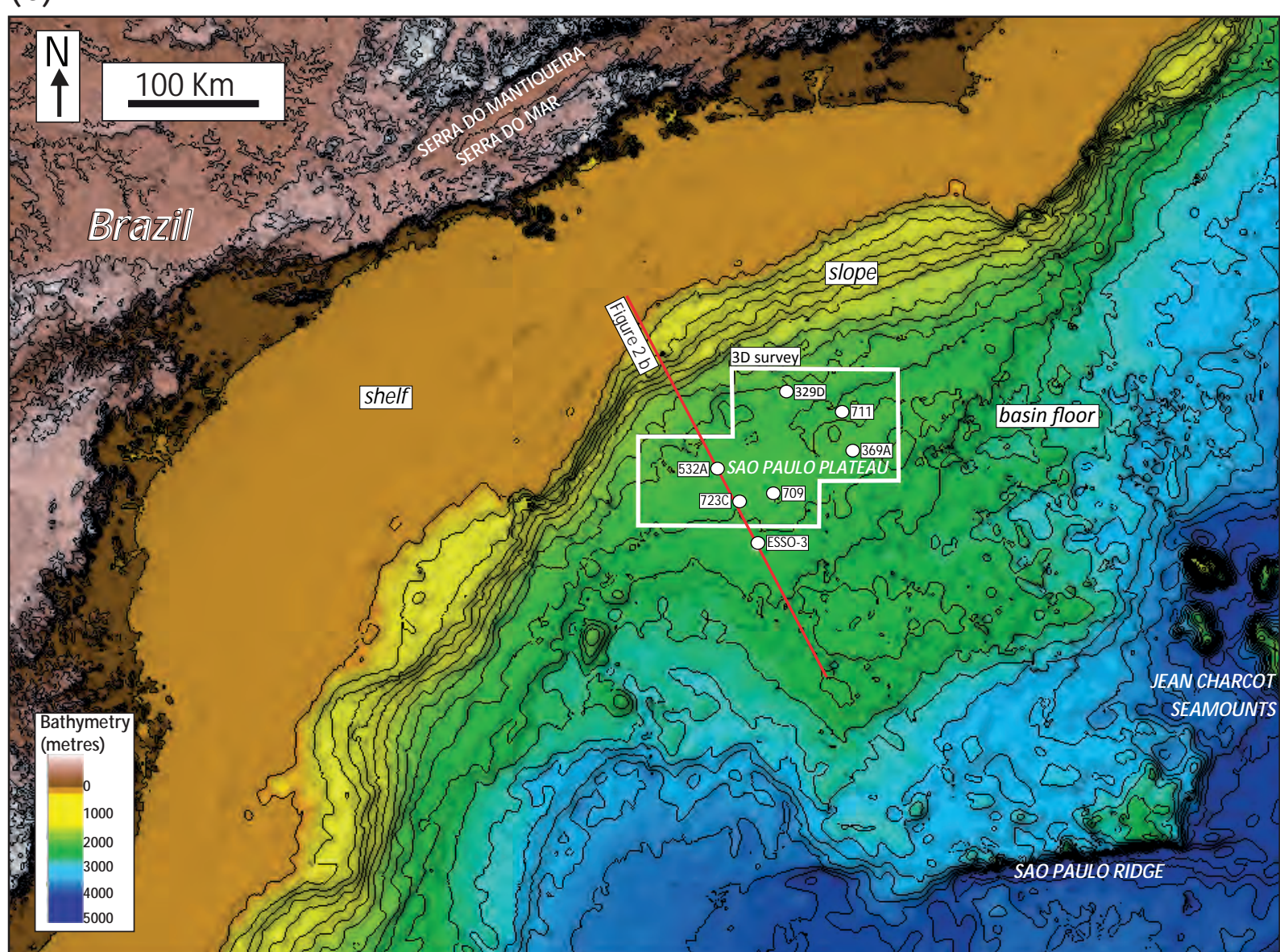

FIGURE 1 (a) Eastern Brazil salt-dominated sedimentary basins highlighting the location of the Santos Basin, offshore Brazil; (b) Study area in the central deep-water Santos Basin. Location of 2D seismic profile, 3D seismic reflection and borehole data available for the study. 
(a)

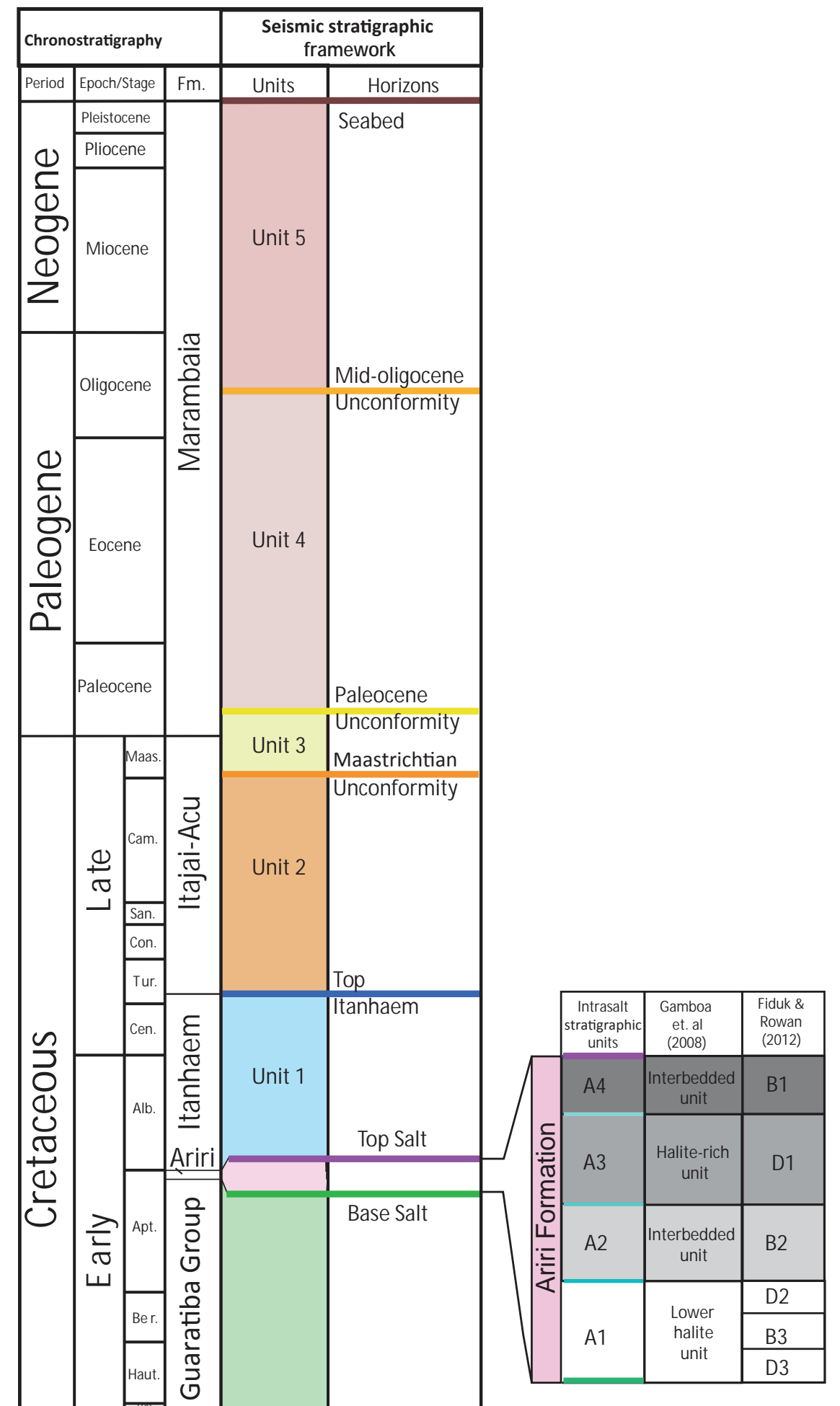

FIGURE 2: (a) Seismic stratigraphic framework; key intrasalt stratigraphic intervals A1-A4 for this and previous studies (Jackson et al., 2014, 2015; Rodriguez et al.(a) in press). B1, B2 and B3 refer to competent layers or 'beams' defined by high amplitude continuous reflections. D1, D2 and D3 refer to ductile detachment zones defined by acoustically transparent, poorly continous reflections (Fiduk and Rowan, 2012). (b) 2D depth seismic profile illustrating salt-related structural domains in the Santos Basin. (c) Geoseismic profile with interpreted seismic units. 


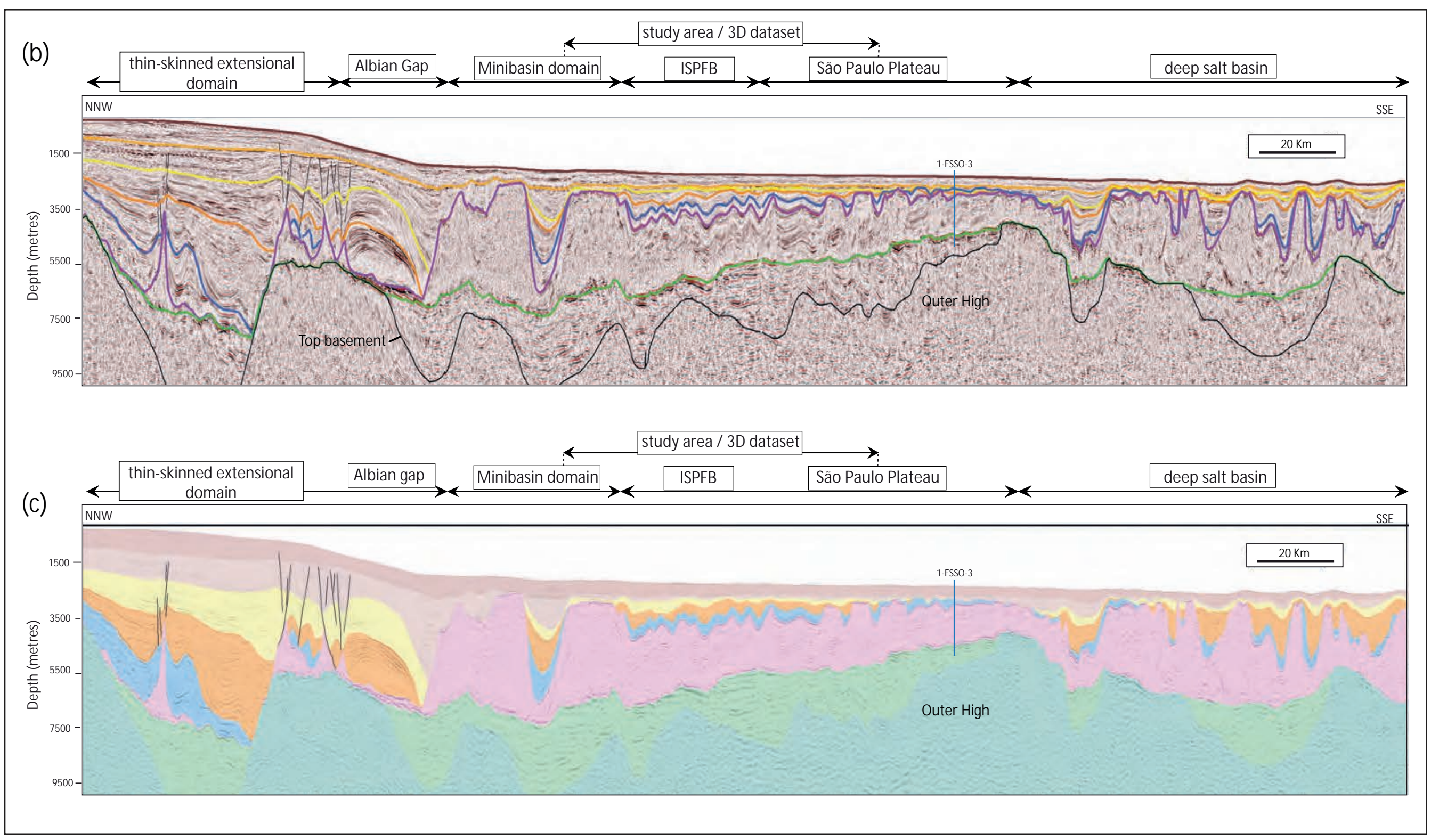


Table 1: Post-salt sediment key input parameters for the basin restoration based on seismic interpretation and well reports available

\begin{tabular}{|c|c|c|c|c|c|c|}
\hline Horizon age ( $\mathrm{Ma}$ ) & Horizon name & Unit name & Lithology & $\begin{array}{l}\text { Near-surface } \\
\text { porosity (\%) }\end{array}$ & $\begin{array}{c}\text { Decay constant } \\
(1 / \mathrm{km})\end{array}$ & M atrix density $(\mathrm{g} / \mathrm{cc})$ \\
\hline 0 & Top Marambaia (Seabed) & Unit 5 & $\begin{array}{l}90 \% \text { shale } \\
10 \% \text { sand }\end{array}$ & 61.6 & 0.49 & 2.71 \\
\hline$\sim 28$ & Mid Oligocene Unconformity & Unit 4 & $\begin{array}{l}80 \% \text { shale } \\
20 \% \text { sand }\end{array}$ & 60.2 & 0.46 & 2.71 \\
\hline-60 & Paleocene unconformity & Unit 3 & $\begin{array}{l}40 \% \text { shale } \\
60 \% \text { sand }\end{array}$ & 54.6 & 0.37 & 2.68 \\
\hline-67 & Maastrichtian unconformity & Unit 2 & $\begin{array}{l}60 \% \text { shale } \\
40 \% \text { sand }\end{array}$ & 57.4 & 0.41 & 2.69 \\
\hline-95 & Top Itanhaem & Unit 1 & $\begin{array}{c}70 \% \text { shale } \\
30 \% \text { limestone }\end{array}$ & 65.1 & 0.57 & 2.72 \\
\hline
\end{tabular}


(a)

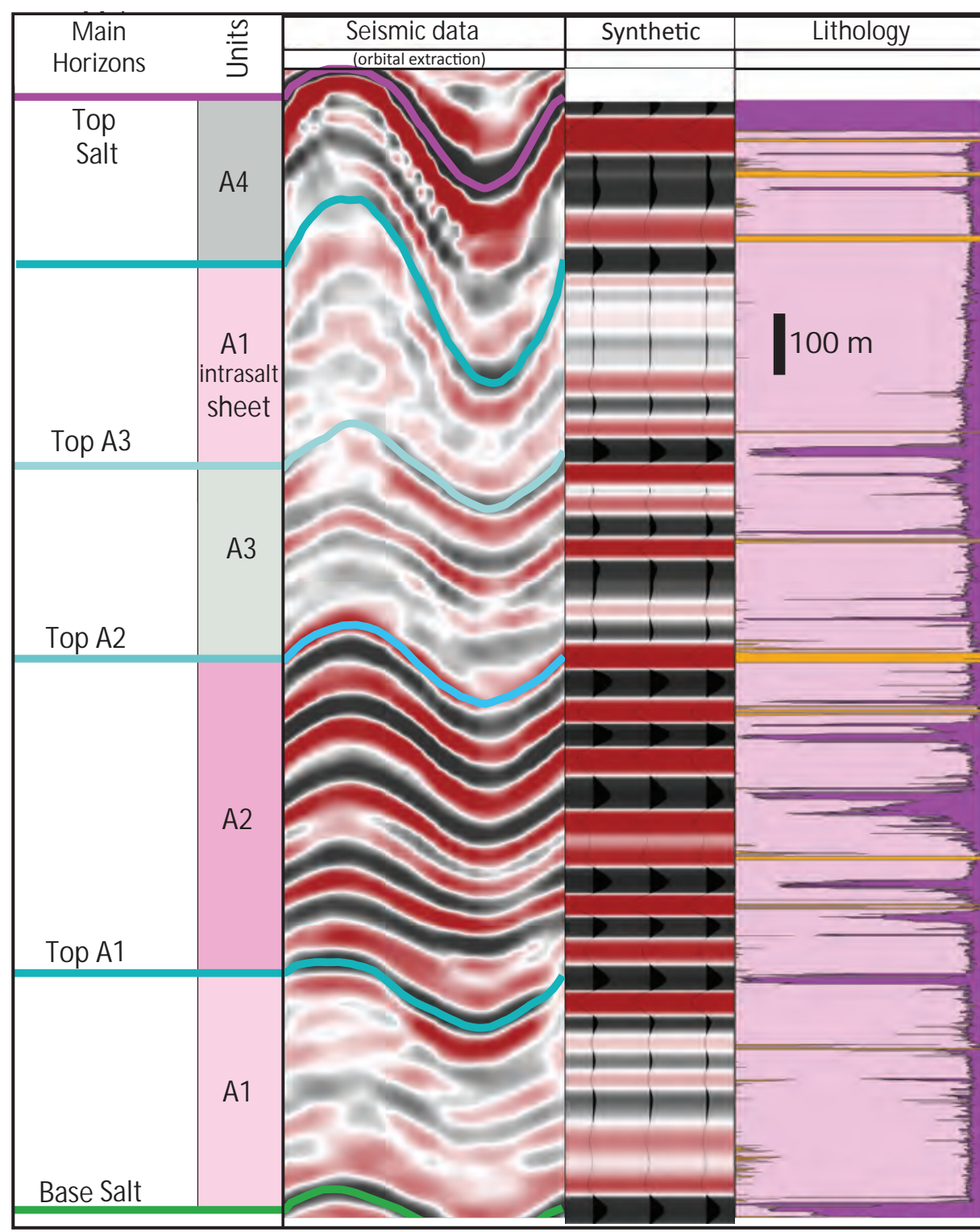

(b)
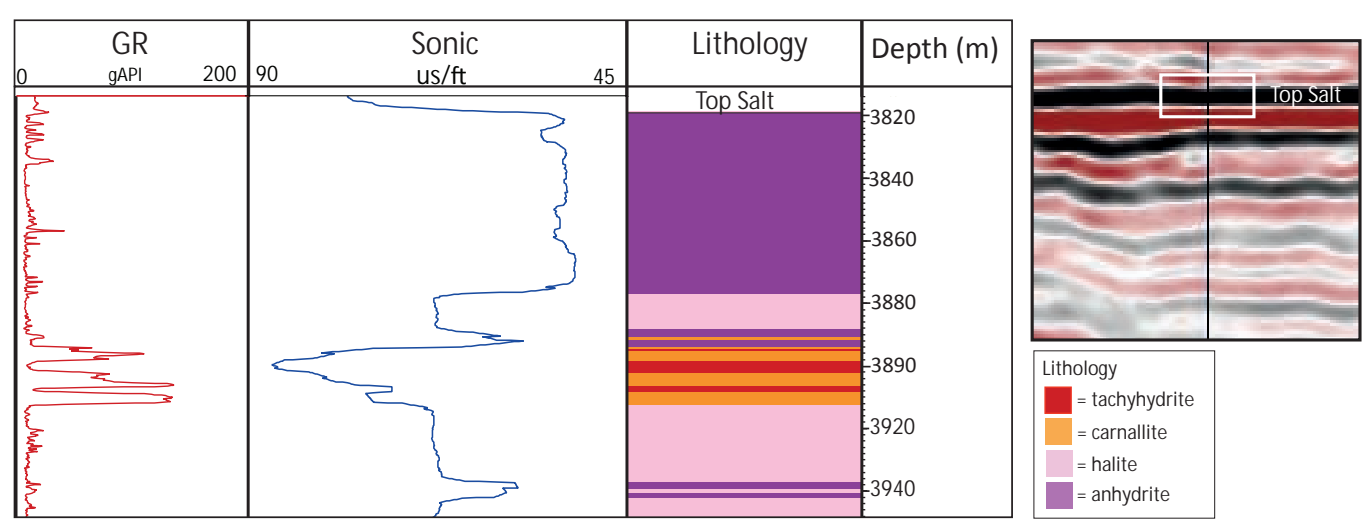

FIGURE 3: (a) Borehole (709) and seismic expression for the intrasalt stratigraphy. A1-A4 intrasalt key stratigraphic intervals are defined by vertical variations in seismic facies and the integration with borehole data. Intrasalt lithology was identified based on the typical well log response for evaporites for a combination of wireline logs; i.e., density (RHOB), sonic (DT), neutron porosity (NPHI) and gamma-ray (GR) (see also. Jackson et al., 2015; Rodriguez et al., in press); (b) Borehole (532A) and seismic expression of the Top Salt in a structurally-low and relatively undeformed area; (c) Borehole (723C) and seismic expression of the post-salt sedimentary overburden. Key post-salt seismic units are defined based on vertical variations in seismic facies and the integration with borehole data.

\begin{tabular}{|l}
\hline Lithology \\
$=$ carnallite \\
$=$ halite \\
$=$ anhydrite
\end{tabular}


(c)

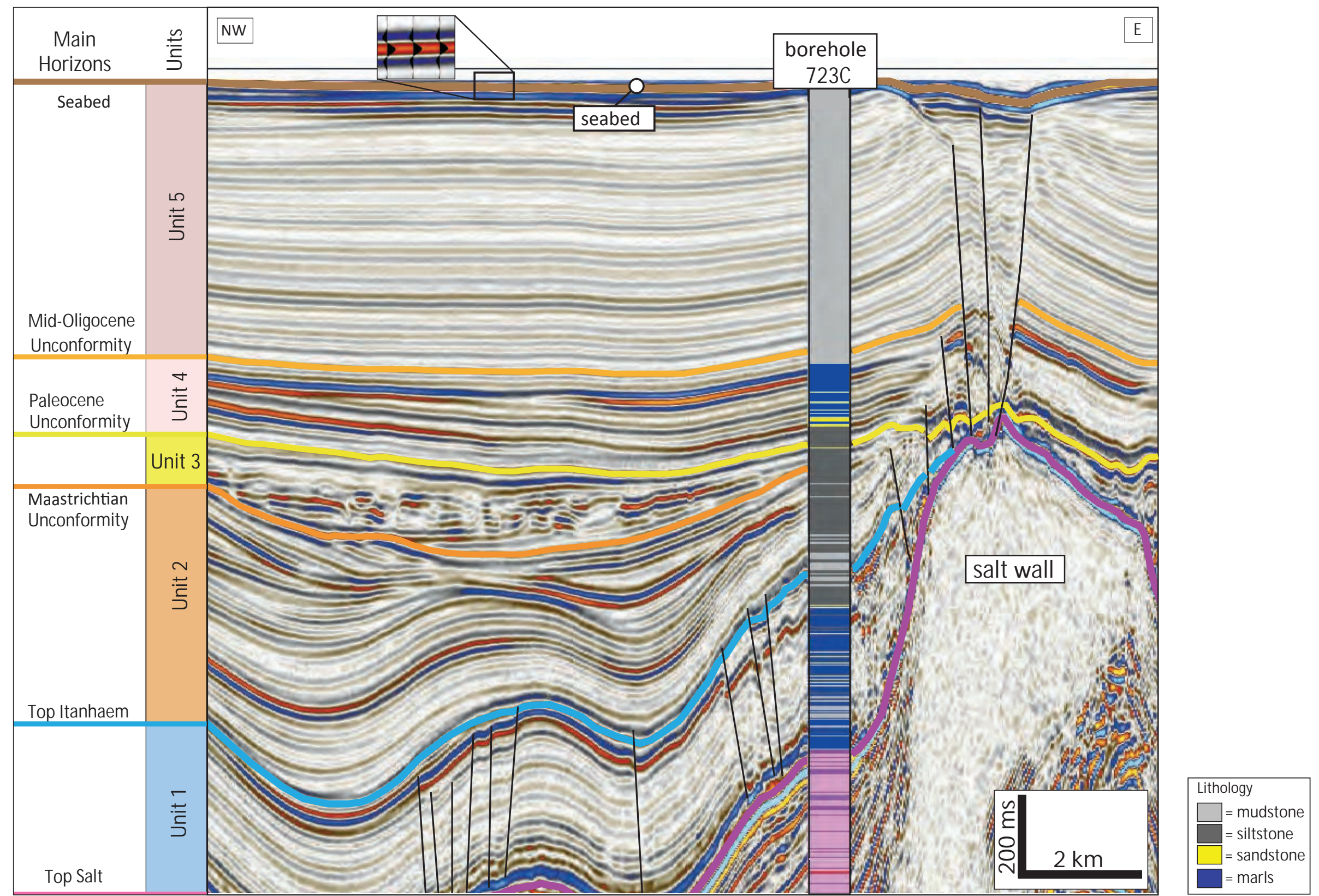


Table 2 : Overburden seismic expression and thickness variations above dissolved rugose crests.

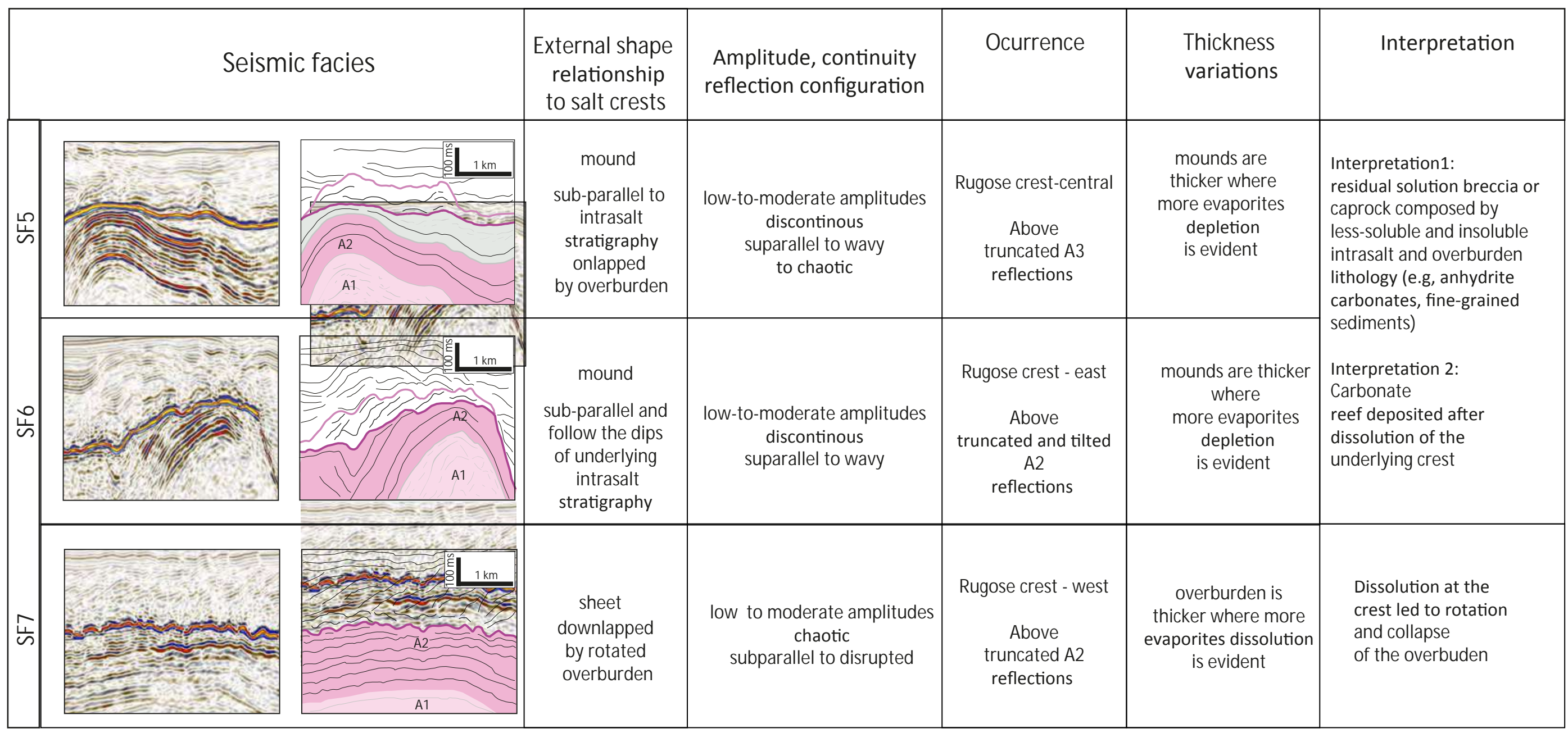


Table 3: Overburden seismic expression and thickness variations above dissolved flat crests.

\begin{tabular}{|c|c|c|c|c|c|c|c|}
\hline \multicolumn{3}{|c|}{ Seismic facies } & $\begin{array}{c}\text { External shape } \\
\text { relationship }\end{array}$ & $\begin{array}{l}\text { Amplitude, continuity } \\
\text { reflection configuration }\end{array}$ & Ocurrence & $\begin{array}{l}\text { Thickness } \\
\text { variations }\end{array}$ & Interpretation \\
\hline$\frac{1}{\sqrt{n}}$ & 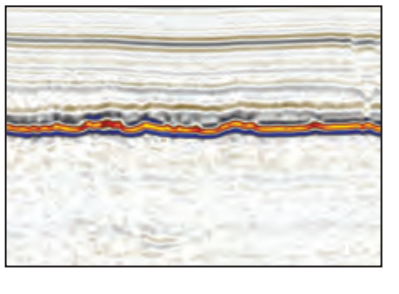 & 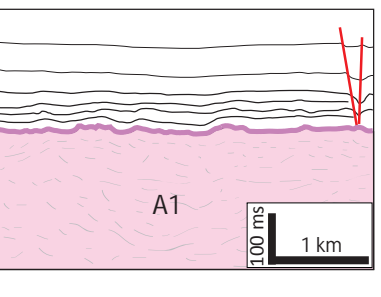 & $\begin{array}{l}\text { sheet drape } \\
\text { conformable to } \\
\text { top salt }\end{array}$ & $\begin{array}{l}\text { low-to-moderate amplitudes } \\
\text { continuous } \\
\text { parallel to sub-parallel }\end{array}$ & $\begin{array}{l}\text { Flat crest - east } \\
\text { Above A1- } \\
\text { allocthonous } \\
\text { intrasalt sheet }\end{array}$ & \begin{tabular}{|} 
minor thickness \\
variations c. $\pm 50 \mathrm{~ms}$ \\
local depocenters \\
up to c.80ms \\
above lows on top salt
\end{tabular} & $\begin{array}{l}\text { fine-grained lithology } \\
\text { deposited on flat crest } \\
\text { before dissolution } \\
\text { post-depositional } \\
\text { dissolution not too obvious } \\
\text { at seismic scale }\end{array}$ \\
\hline$\frac{N}{n}$ & 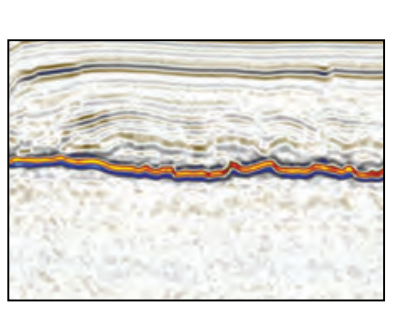 & 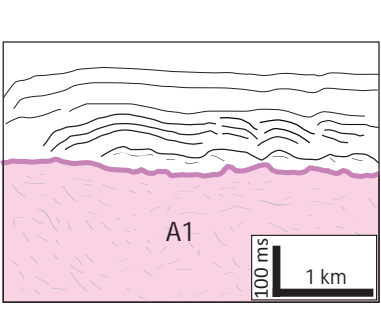 & $\begin{array}{l}\text { sheet to mound } \\
\text { apparent downlap } \\
\text { on top salt }\end{array}$ & $\begin{array}{l}\text { low-to-moderate amplitudes } \\
\text { semicontinuous to disrupted } \\
\text { parallel to sub-parallel }\end{array}$ & $\begin{array}{l}\text { Flat crest - central } \\
\text { Above flat } \\
\text { Al-allocthonous } \\
\text { intrasalt sheet }\end{array}$ & \begin{tabular}{|} 
minor thickness \\
variations c. $\pm 75 \mathrm{~ms}$ \\
local depocenters \\
up to c.125 ms \\
above lows on top salt
\end{tabular} & $\begin{array}{l}\text { fine-grained lithology } \\
\text { deposited on salt crest } \\
\text { before dissolution } \\
\text { post-depositional } \\
\text { dissolution led to local } \\
\text { collapse and deformation } \\
\text { within the overburden }\end{array}$ \\
\hline$\frac{m}{n}$ & 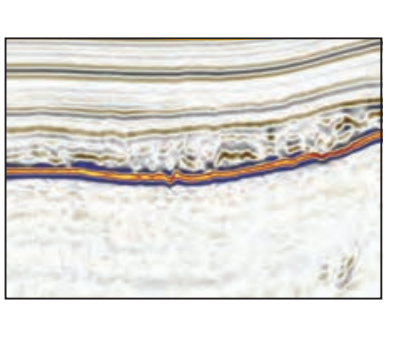 & 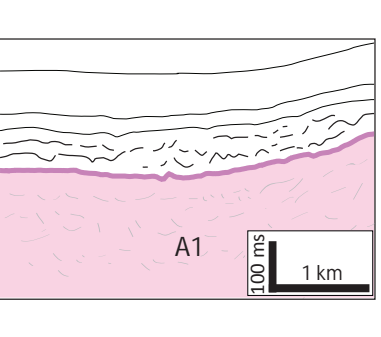 & $\begin{array}{l}\text { sheet to wedge } \\
\text { conformable \& } \\
\text { apparent } \\
\text { downlaps } \\
\text { on top salt }\end{array}$ & $\begin{array}{l}\text { low-to-moderate amplitudes } \\
\text { discontinuous } \\
\text { wavy to chaotic }\end{array}$ & $\begin{array}{l}\text { Flat crest - central } \\
\text { Above lows on } \\
\text { Al-allocthonous } \\
\text { intrasalt sheet }\end{array}$ & \begin{tabular}{|} 
minor thickness \\
variations c. $\pm 75 \mathrm{~ms}$ \\
local depocenters \\
up to c.125 ms \\
above lows on top salt
\end{tabular} & $\begin{array}{l}\text { fine-grained lithology } \\
\text { deposited on salt crest } \\
\text { before dissolution } \\
\text { post-depositional } \\
\text { dissolution led to local } \\
\text { collapse and deformation } \\
\text { within the overburden }\end{array}$ \\
\hline$\frac{\pi}{n}$ & 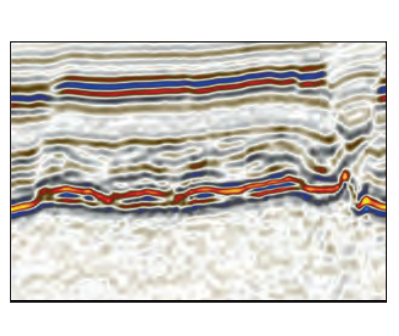 & A1 & $\begin{array}{l}\text { sheet to mound } \\
\text { conformable \& } \\
\text { apparent } \\
\text { downlaps } \\
\text { on top salt }\end{array}$ & $\begin{array}{l}\text { moderate to high amplitudes } \\
\text { semicontinuos } \\
\text { subparallel to wavy }\end{array}$ & $\begin{array}{l}\text { Flat crest - west } \\
\text { Above discrete } \\
\text { mounds on top } \\
\text { salt }\end{array}$ & \begin{tabular}{|} 
minor thickness \\
variations c. $\pm 100 \mathrm{~ms}$ \\
local depocenters \\
up to c.150 ms \\
above lows on top salt
\end{tabular} & $\begin{array}{l}\text { fine-grained lithology } \\
\text { deposited on salt crest } \\
\text { during dissolution } \\
\text { syn-depositional } \\
\text { dissolution led to local } \\
\text { collapse and deformation } \\
\text { within the overburden }\end{array}$ \\
\hline
\end{tabular}



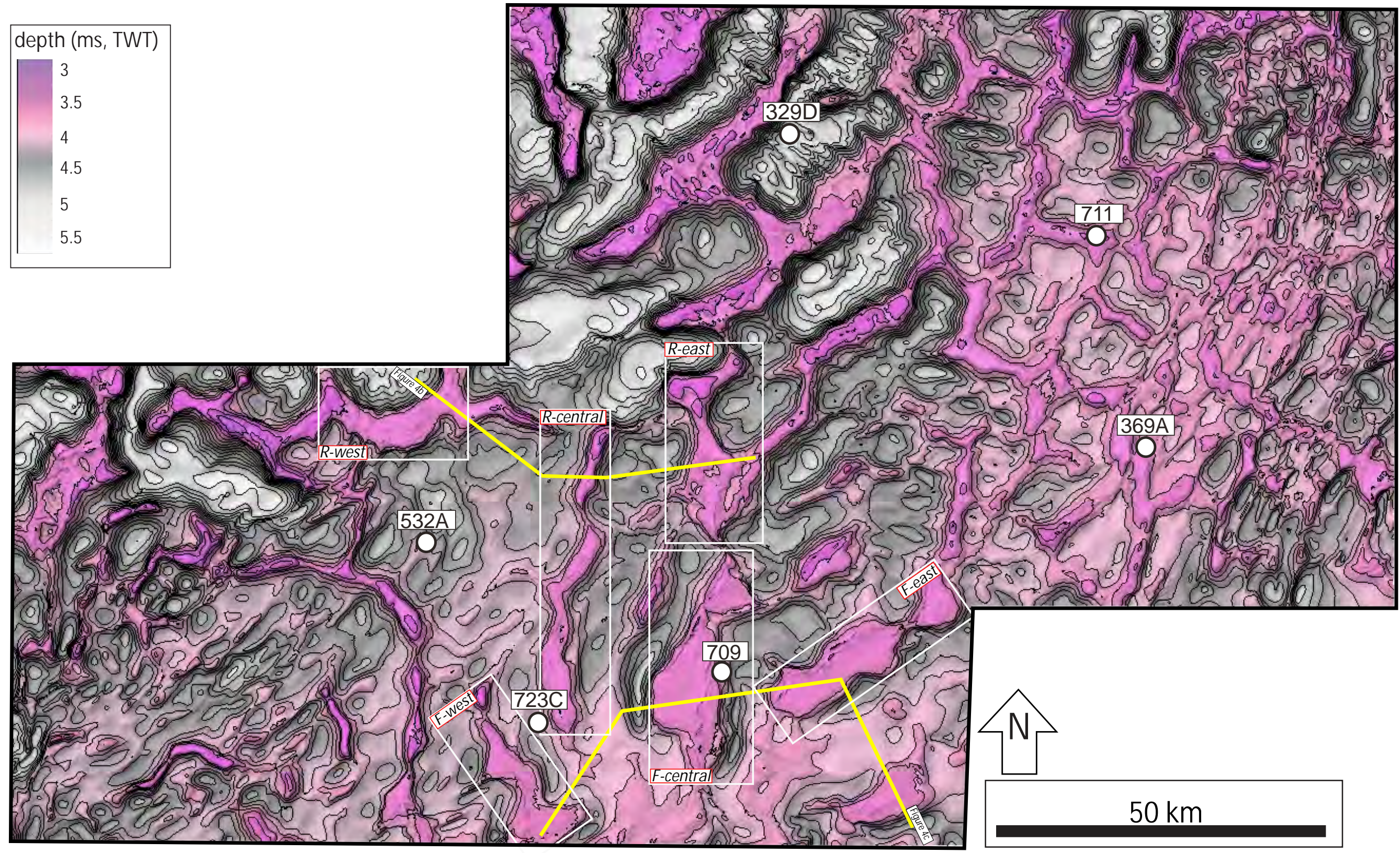

FIGURE 4: (a) Top salt structural map with locations of salt walls of interest 


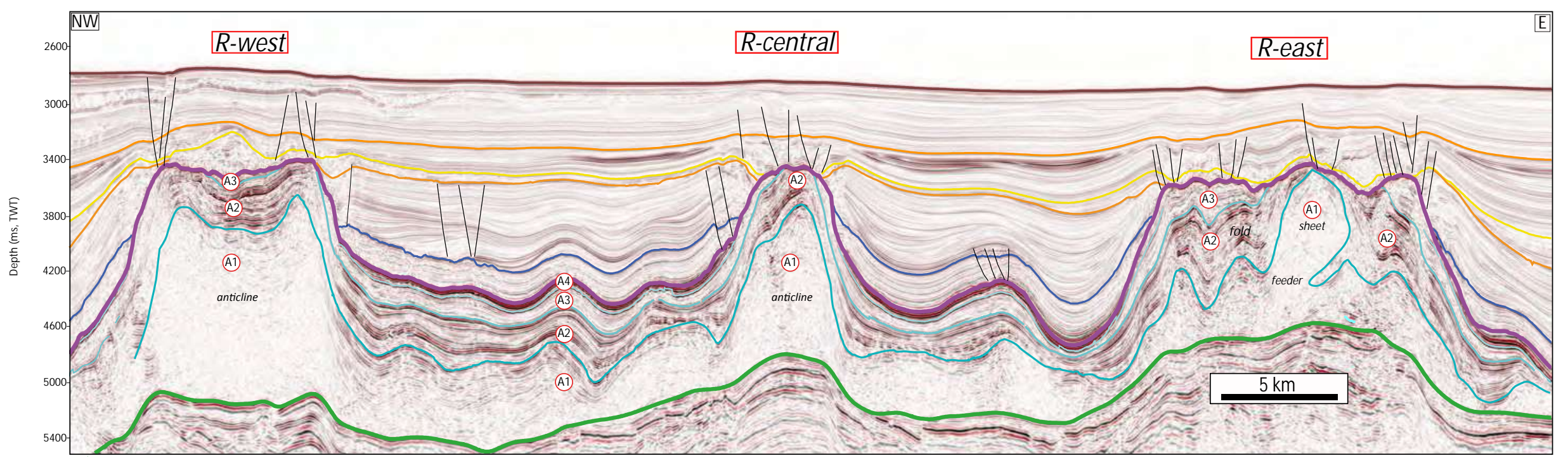

Figure 4 b: Seismic section across salt diapirs with rounded and rugose crests

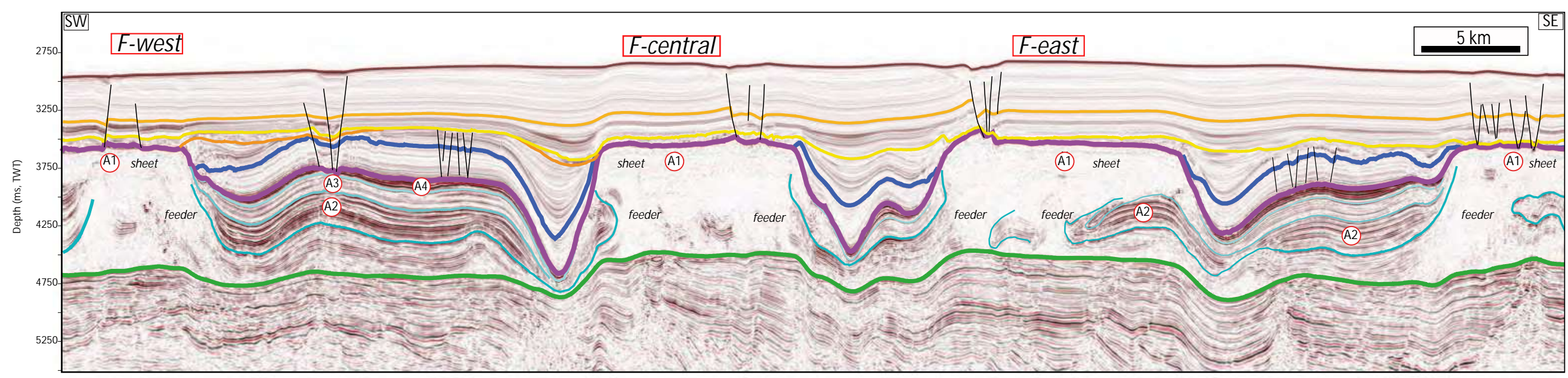

Figure 4 c: Seismic section across salt diapirs with flat crests 


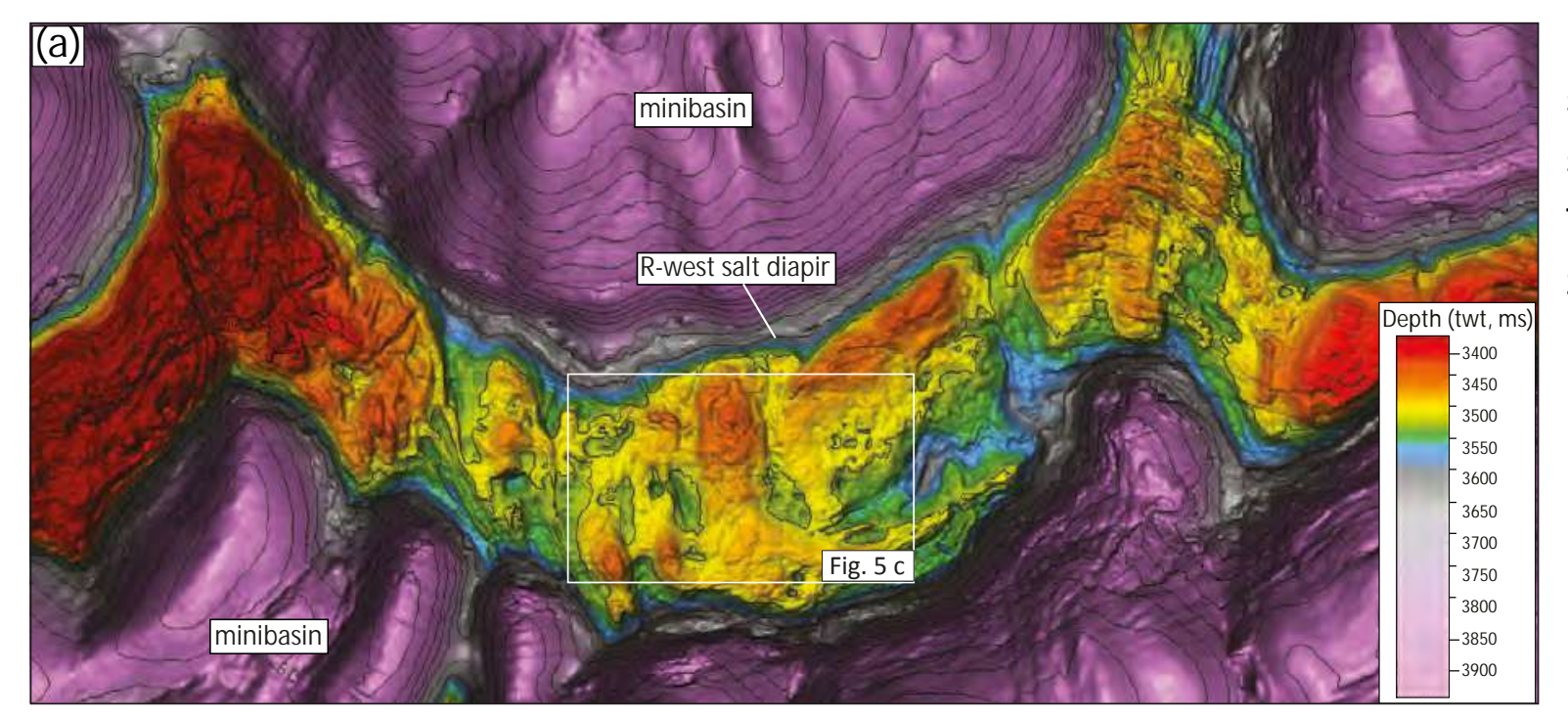

FIGURE 5: Seismic expression of salt dissolution-related sinkholes: (a) R-west top salt structural map; (b) Salt karst along Top Salt and intrasalt stratigraphy subcropping the R-west salt diapir; (c) Amplitude contrast attribute map for R-west Top Salt highlighting the sinkholes along Top Salt, see Figure 5a for location; (d) Seismic section along the crest of R-east illustrating the geometry of sinkholes (indicated by white arrows) and their relationship to halite-rich A3 intrasalt unit. Location is shown on Figure 5c; (e) Sweetness attribute of the seismic section on (d)
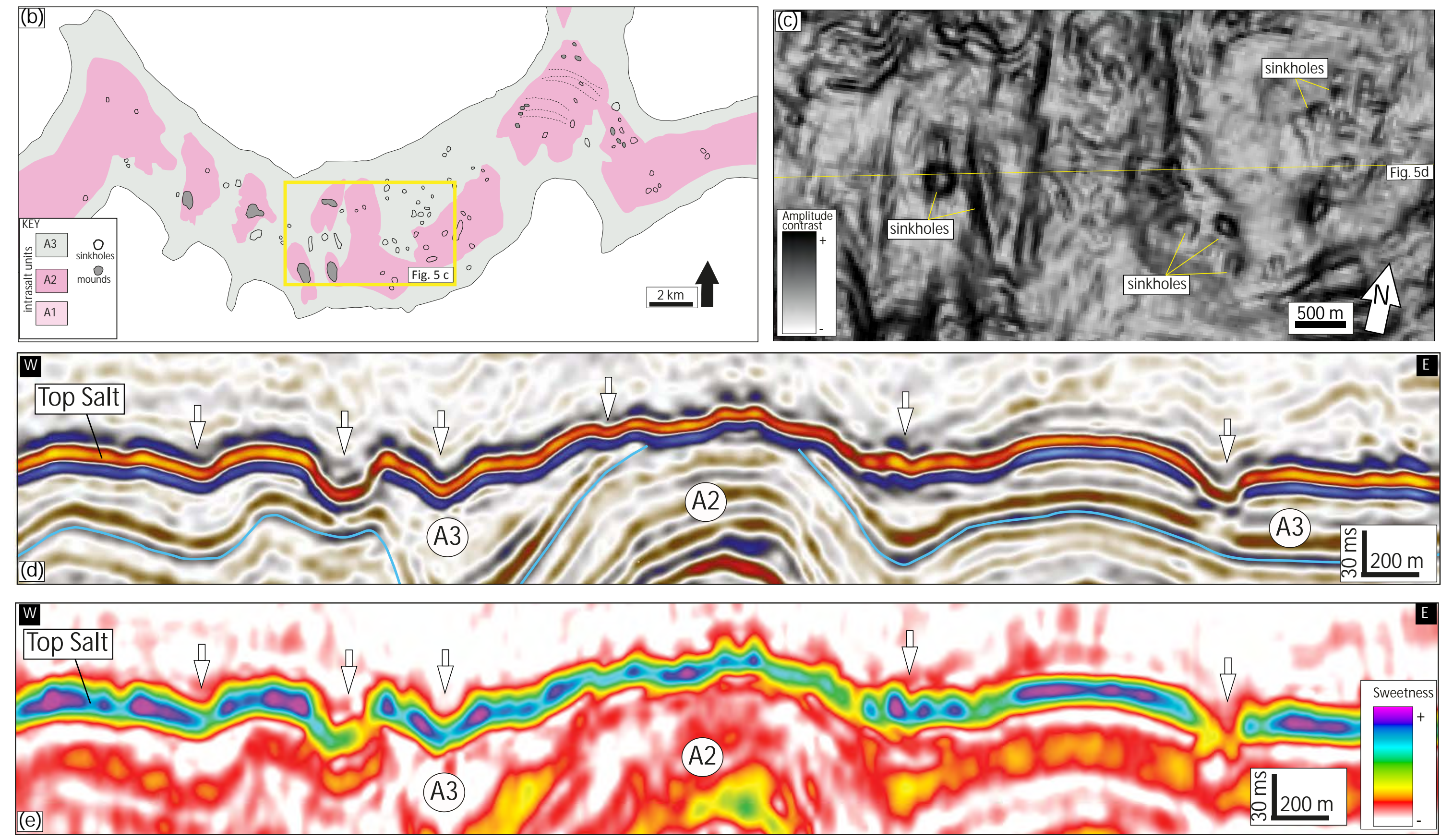
FIGURE 6: Seismic expression of salt dissolution-related sinkholes: (a) R-east top salt structural map; (b) Salt karst along Top Salt and Intrasalt stratigraphy subcropping R-east salt diapir; (c) Amplitude contrast attribute map for R-east Top Salt highlighting the sinkholes along Top Salt, see Figure 6a for location; (d) Seismic section along the crest of R-east illustrating the geometry of sinkholes (indicated by white arrows) and their relationship to dipping-A2 intrasalt stratigraphy. Location is shown on Figure 6c; (e) Chaos attribute of the seismic section on Figure $6 \mathrm{~d}$ highlighting the sinkholes along the Top Salt.
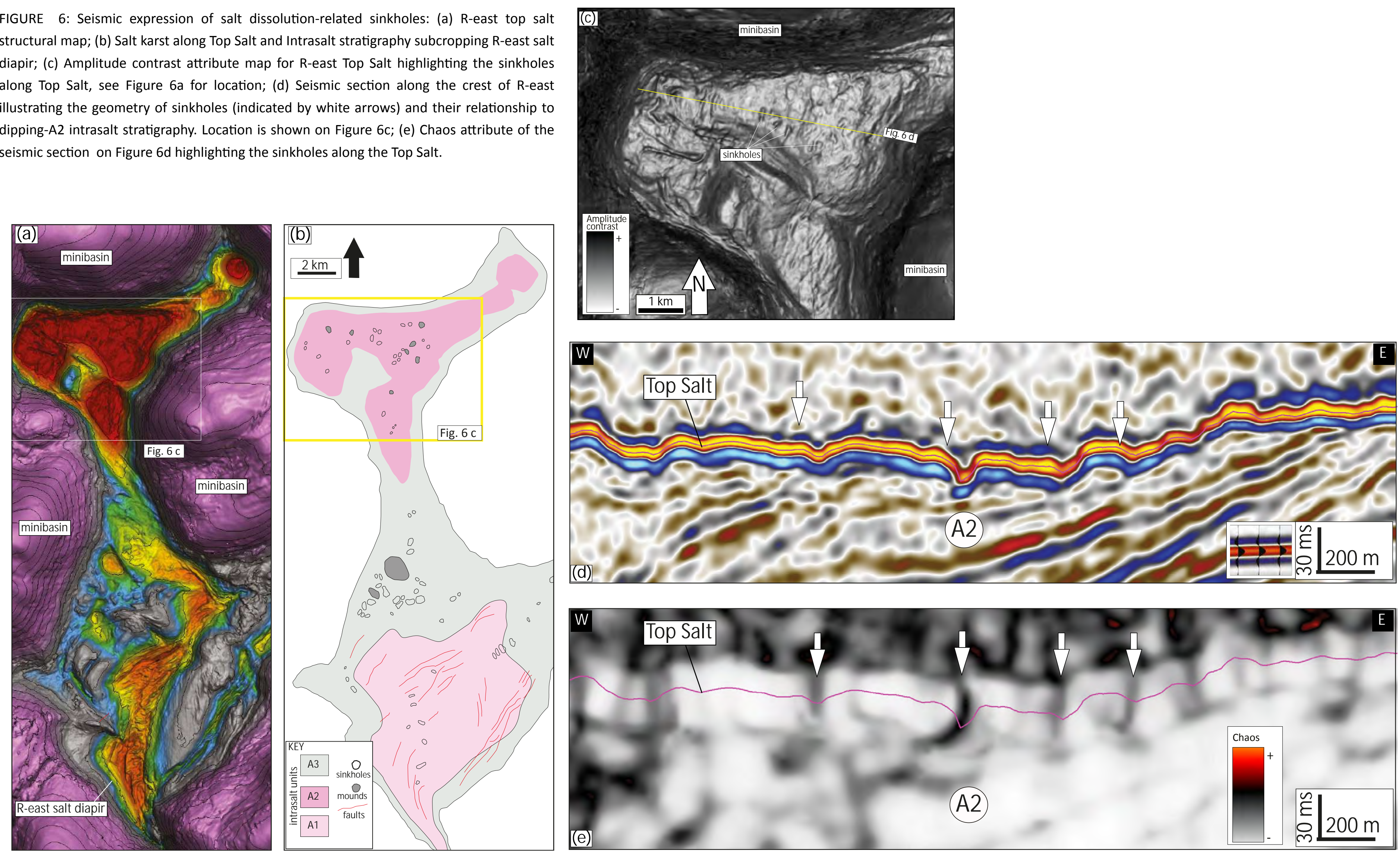


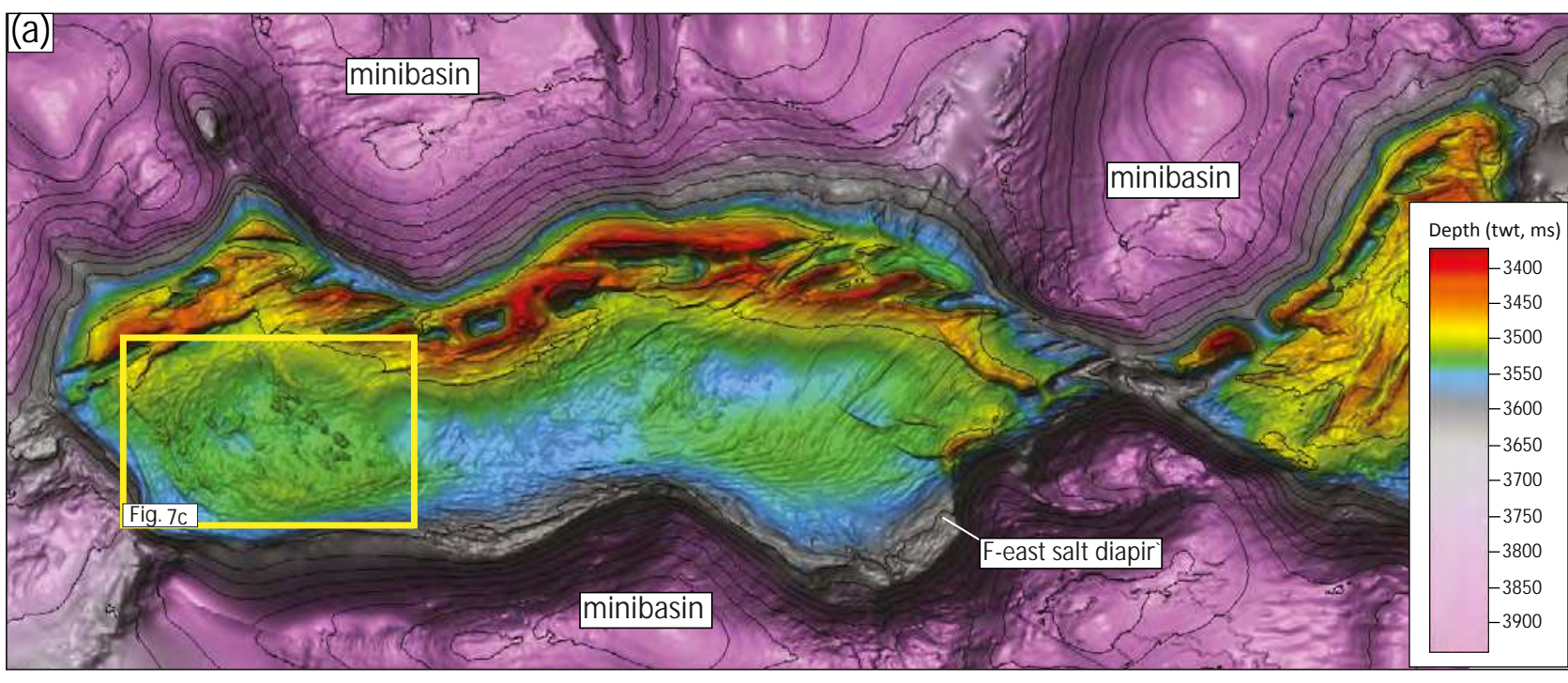

FIGURE 7. Seismic expression residual mounds: (a) Feast top salt structural map; (b) Intrasalt unit subcropping F-east salt diapir; (c) Amplitude contrast attribute map for F-east Top Salt highlighting residual mounds above the nearly-horizontal Top Salt; (d) Seismic section along the crest of F-east illustrating residual mounds above the main top salt level (mounds are indicated by white arrows). See Figure 7c for location; (e) Sweetness attribute for section on Figure $7 d$ highlighting potential facies variations along the Top Salt.
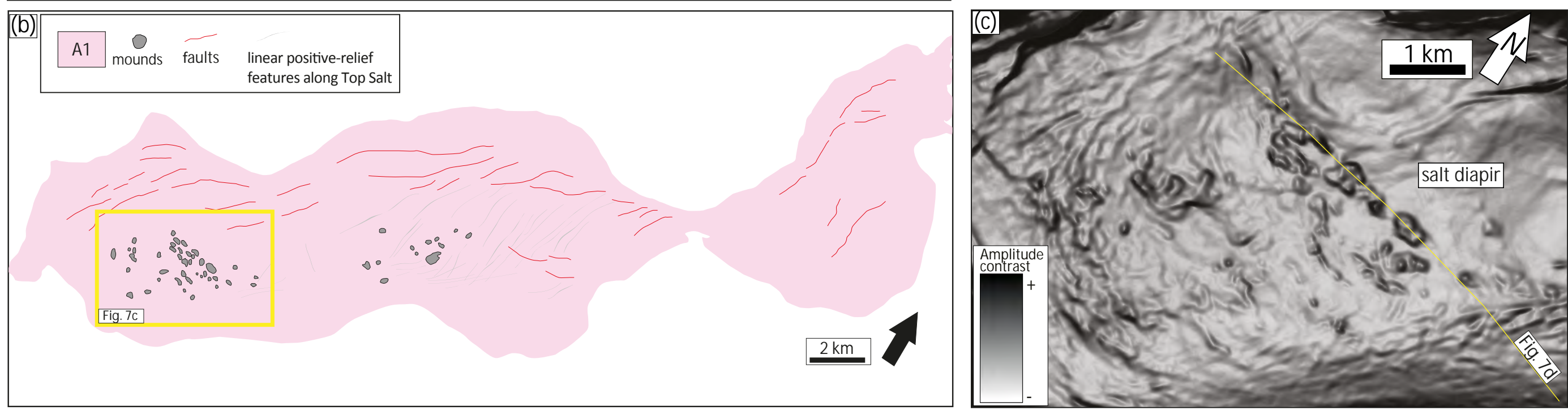

NNW

SSE
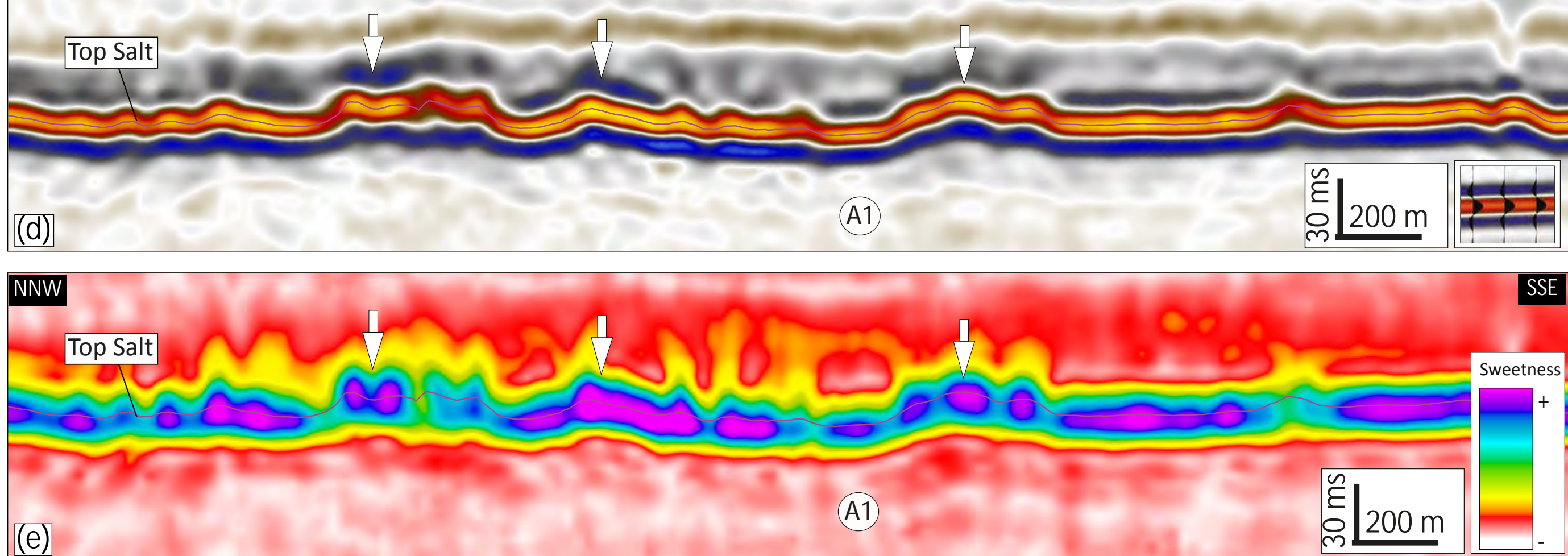

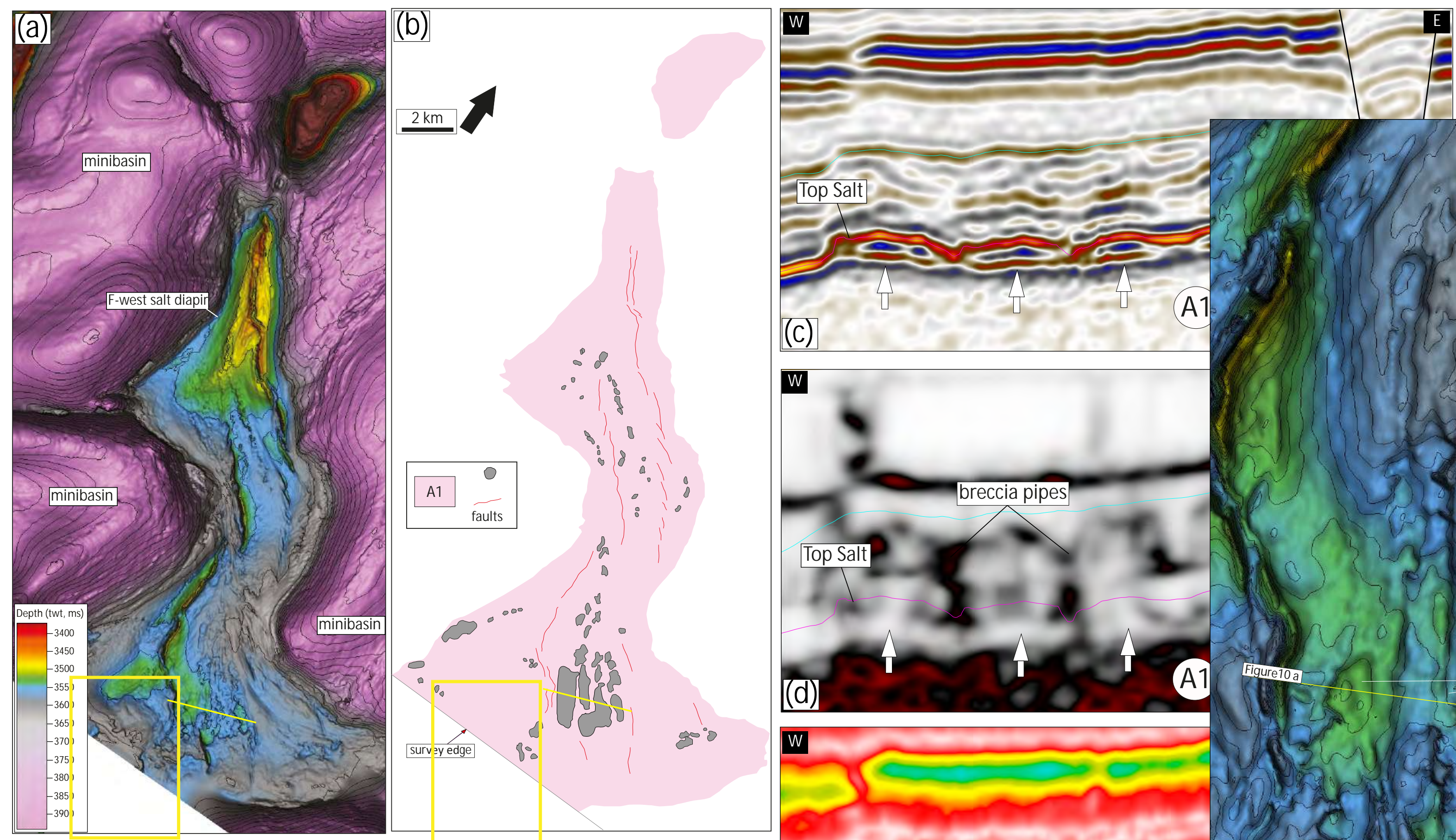

FIGURE 8. Seismic expression of residual mounds: (a) F-west Top Salt structural map; (b) Salt karst along Top Salt and intrasalt stratigraphy subcropping F-west Top Salt; (c) Seismic section along the crest of F-west illustrating residual mounds defined by highly-reflective packages along the Top Salt (mounds are indicated by white arrows). See location on (a) and (b); (d) Chaos attribute for the seismic section on (c) highlighting the discontinuities along the Top Salt and within the overburden; (e) Sweetness attribute for section on (a) illustrating the facies variations along Top Salt and within the mounds

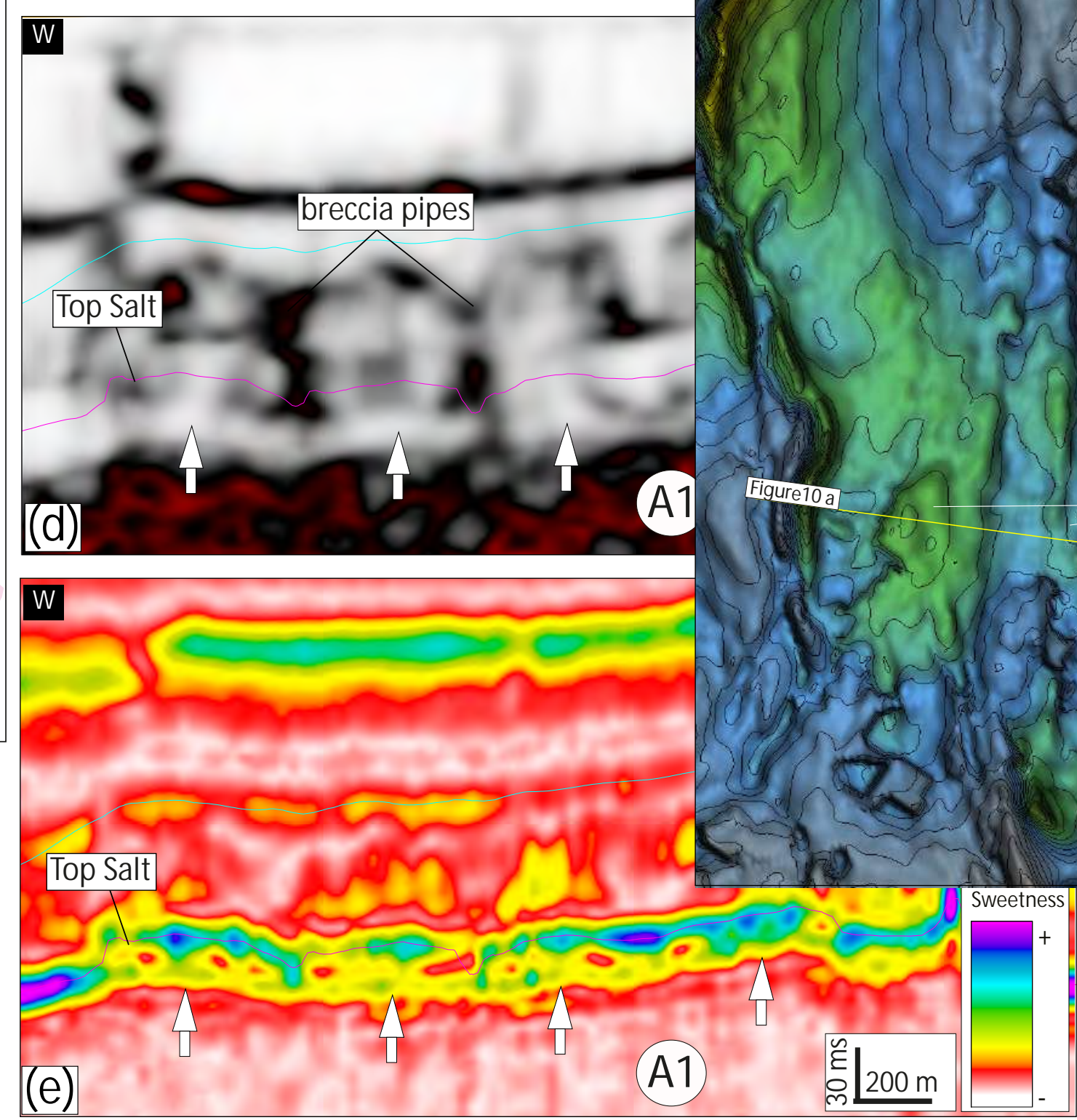



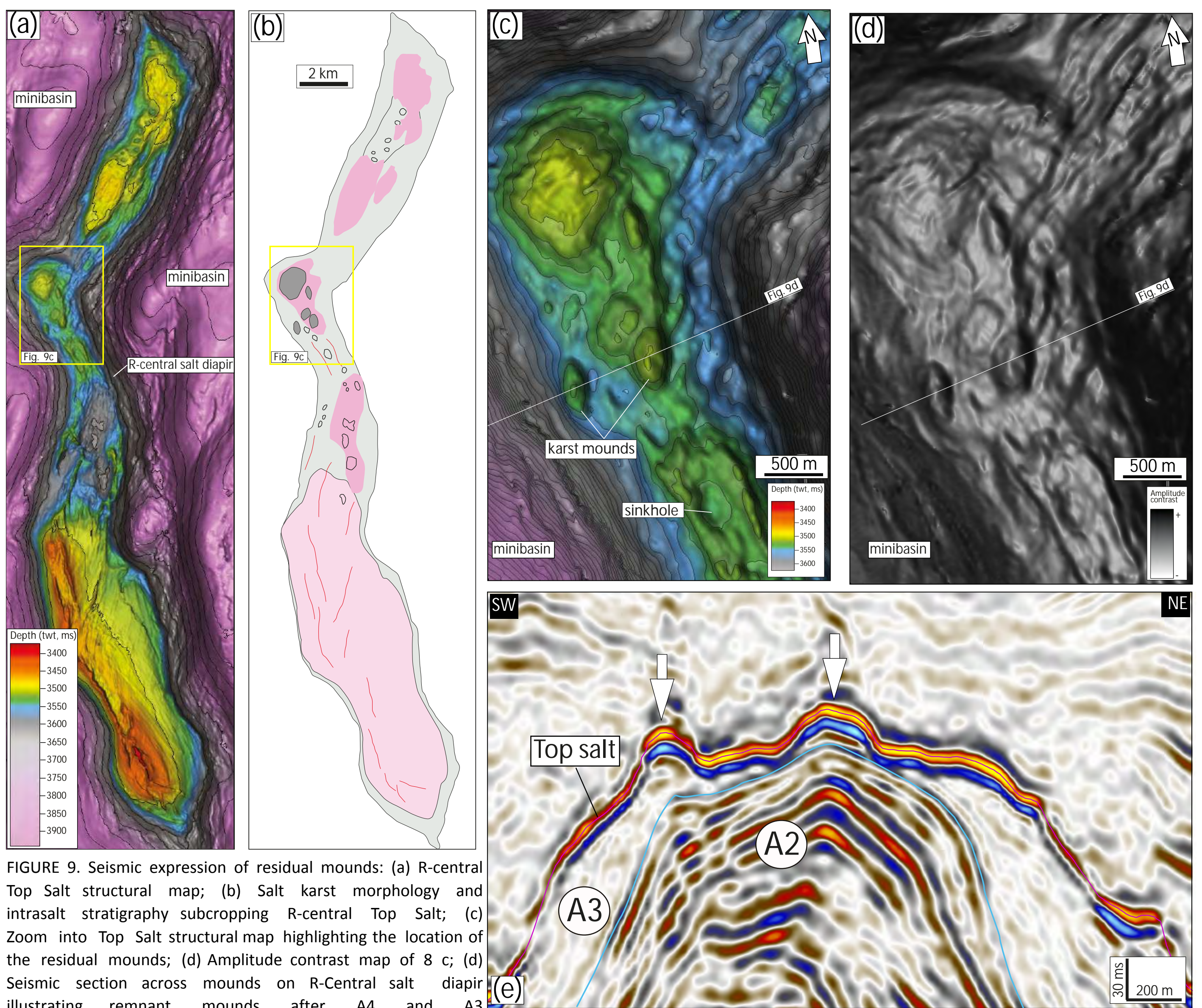

FIGURE 9. Seismic expression of residual mounds: (a) R-central Top Salt structural map; (b) Salt karst morphology and intrasalt stratigraphy subcropping R-central Top Salt; (c)

Zoom into Top Salt structural map highlighting the location of the residual mounds; (d) Amplitude contrast map of $8 \mathrm{c}$; (d) Seismic section across mounds on R-Central salt diapir
illustrating remnant mounds after A4 and A3 dissolution. See (c) and (d) for location. 


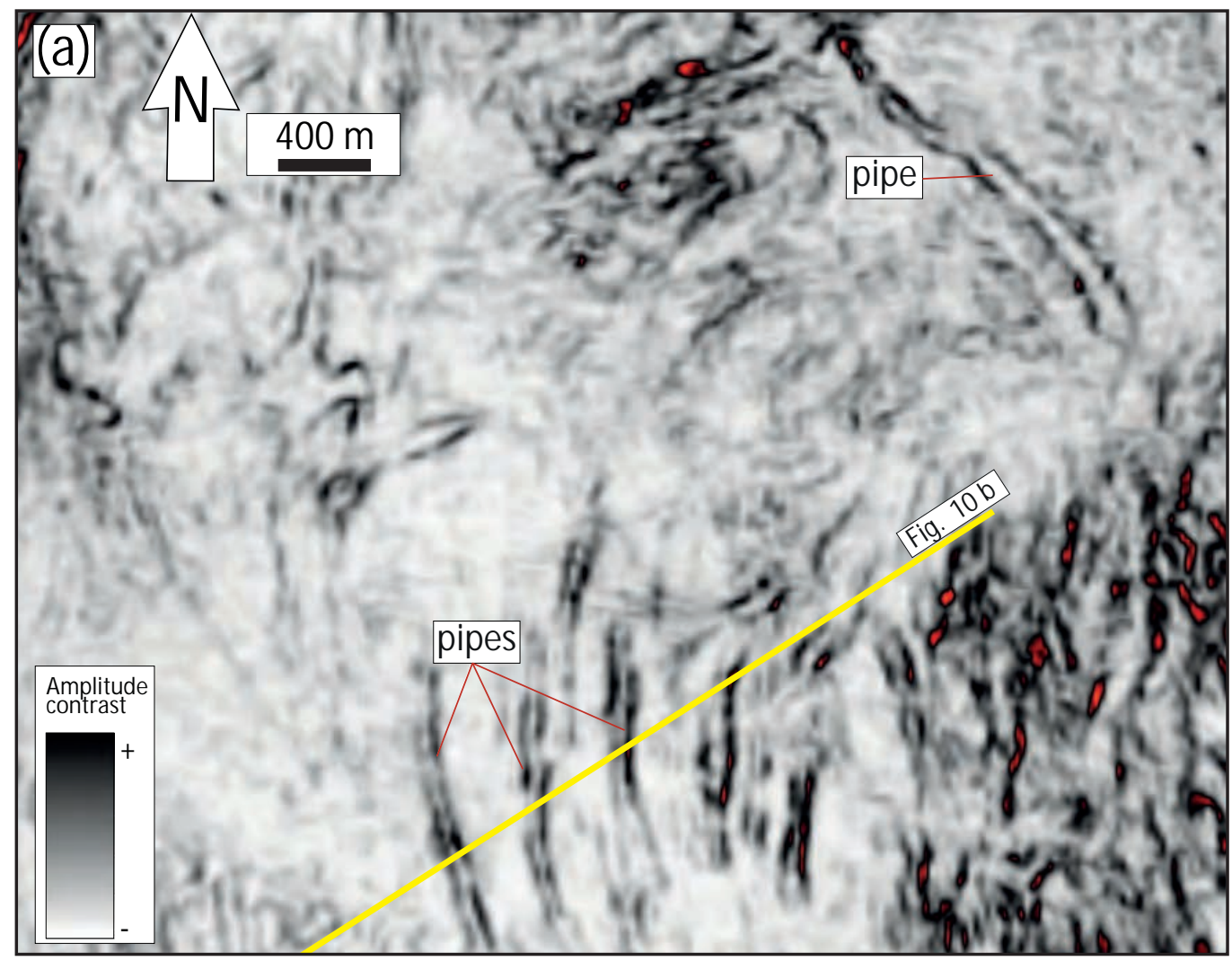

FIGURE 10: Seismic expression of breccia pipes or chimneys within the overburden: (a) Amplitude contrast seismic attribute time slice highlighting the edges of the breccia pipes. See location on Figure 11a; (b) Seismic section accross the crest of F-central and overburden strata. Breccia Pipes are indicated with white arrows; (c) Chaos seismic attribute for the section on Figure $10 \mathrm{~b}$ highlighting the breccias cross-cutting the overburden strata; (d) Sweetness seismic attribute for the section on Figure 10b. Some of the breccia pipes correlate with facies variations along the Top Salt.
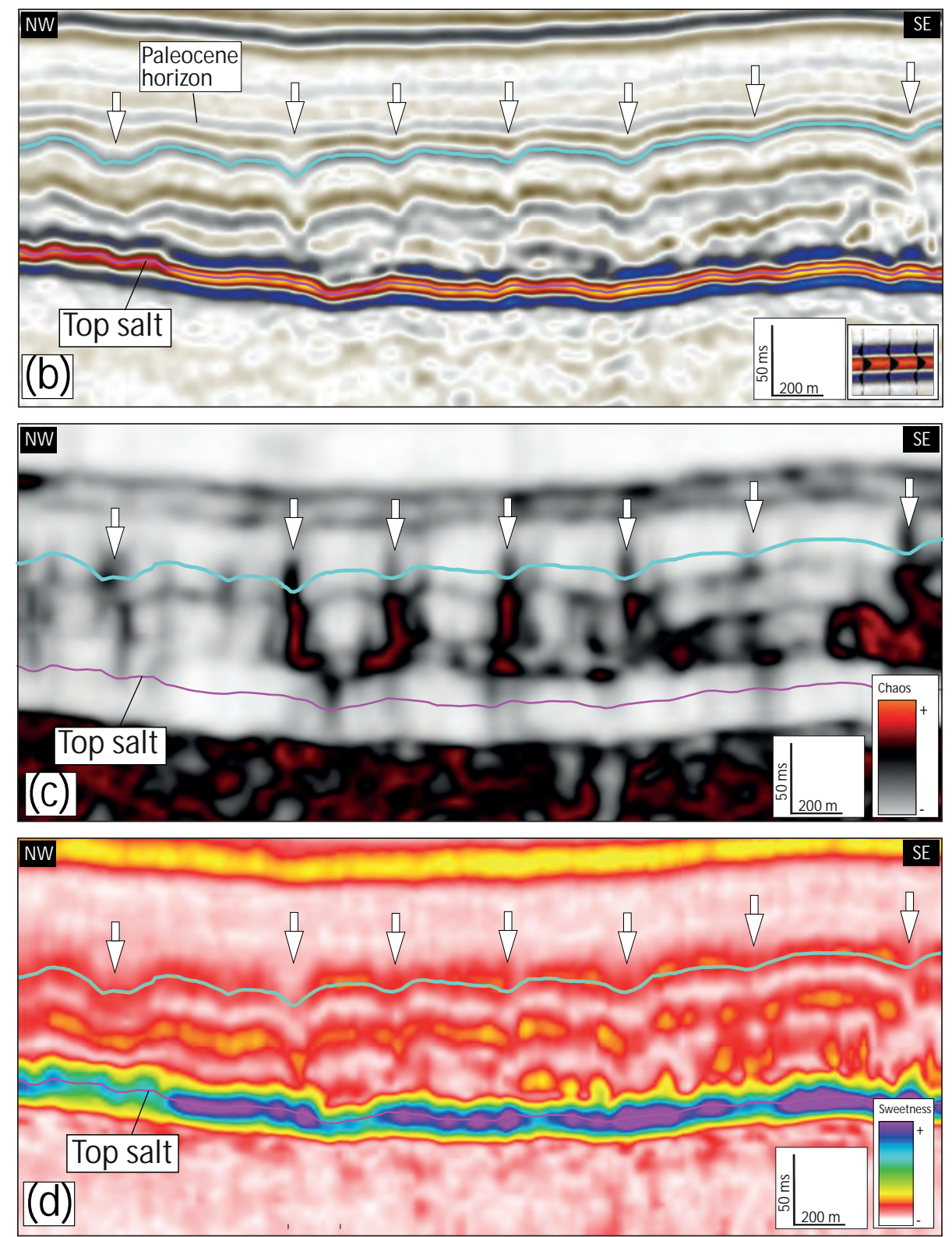

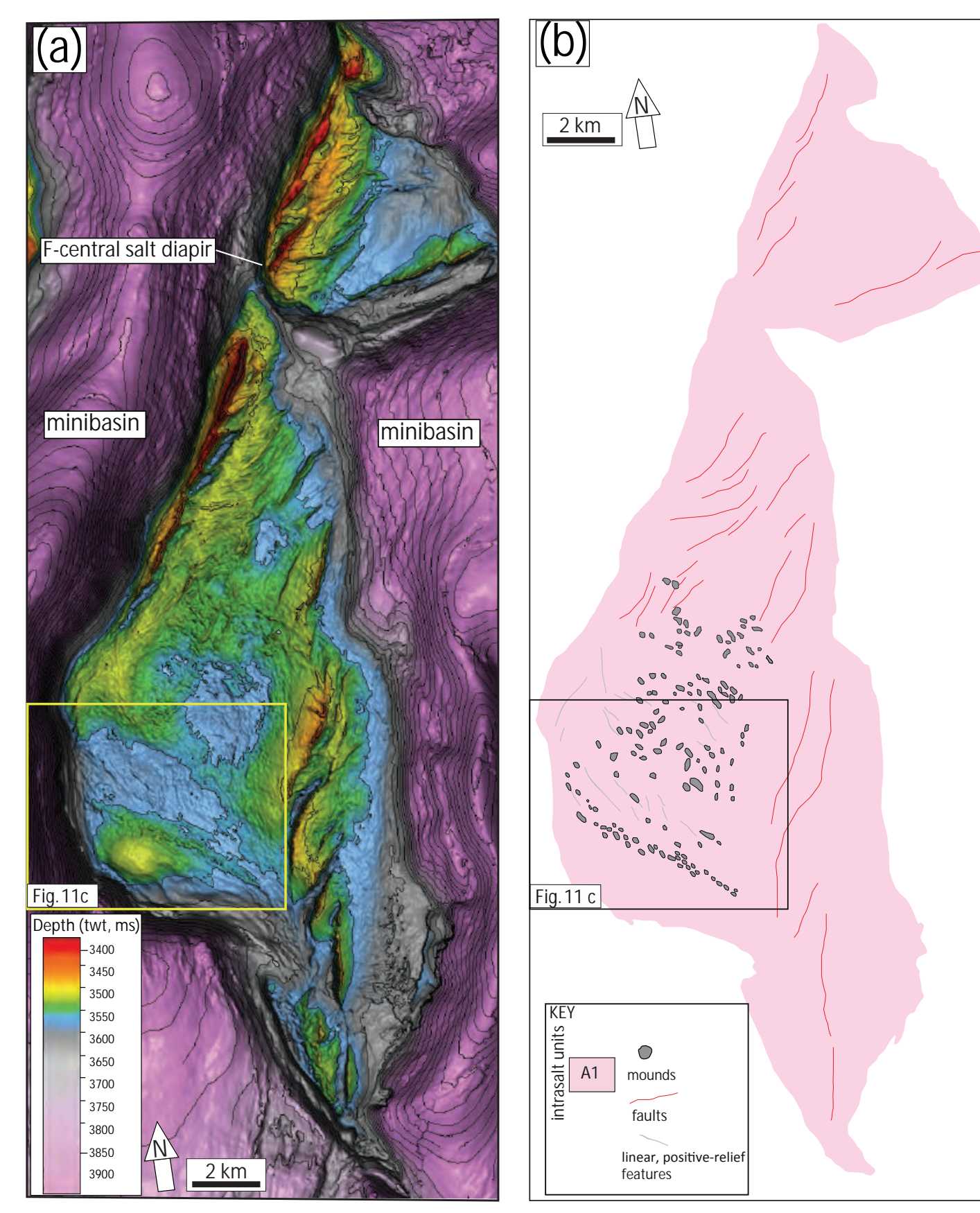

FIGURE 11: (a) F-central Top Salt structural map; (b) Salt karst morphology and intrasalt stratigraphy along the crest of F-central; (c) Structural map for the seismic horizon within the overburden (blue on (d)) highlighting the collapse associated to dissolution of the underlaying halite-rich crest and the top of a channel flanking the salt wall; (d) Seismic section across F-central and the flanking minibasin illustrating the onlap of the channel and discontinuities within the overburden.

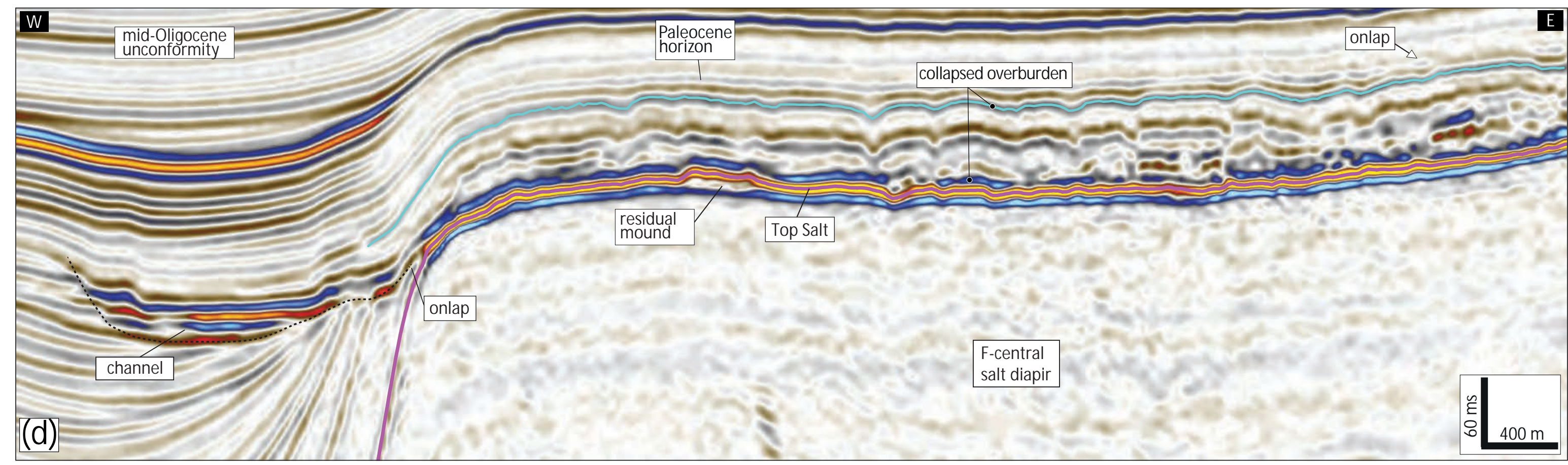


(a)

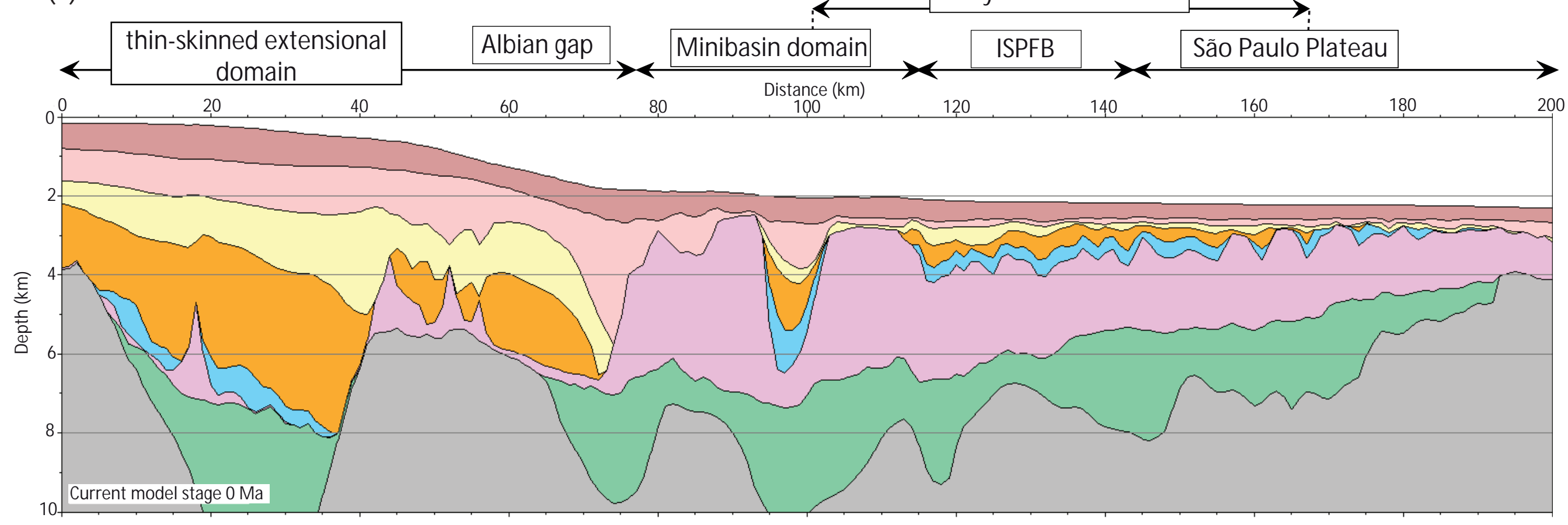

FIGURE 12: (a) Input model used for basin restoration based on the interpretation of 2D depth seismic profile (Figure 2b). See Key on Figure 2a; (b) Minimum Beta Stretching Factor along the 2D seismic profile (after Scotchman et al., 2006); (c) Maximum Beta Stretching Factor along the 2D seismic profile (after Scotchman et al., 2006); (d) Basin restoration to the mid-Oligocene (28 Ma) based on the minimum Beta Stretching Factor profile; (e) Basin restoration to the mid-Oligocene (28 Ma) based on the maximum Beta Stretching Factor profile; (f) Basin restoration to the Paleocene (60 Ma) based on the minimum Beta Stretching Factor profile; (f) Basin restoration to the Paleocene (60 Ma) based on the maximum Beta Stretching Factor profile 
(b)

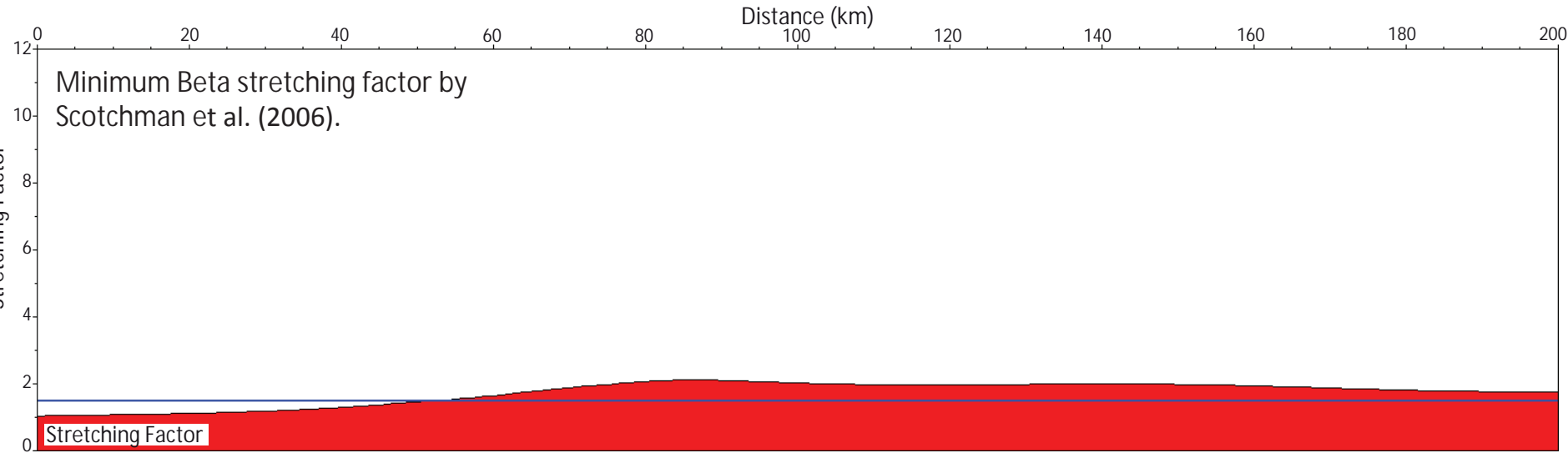

(d)

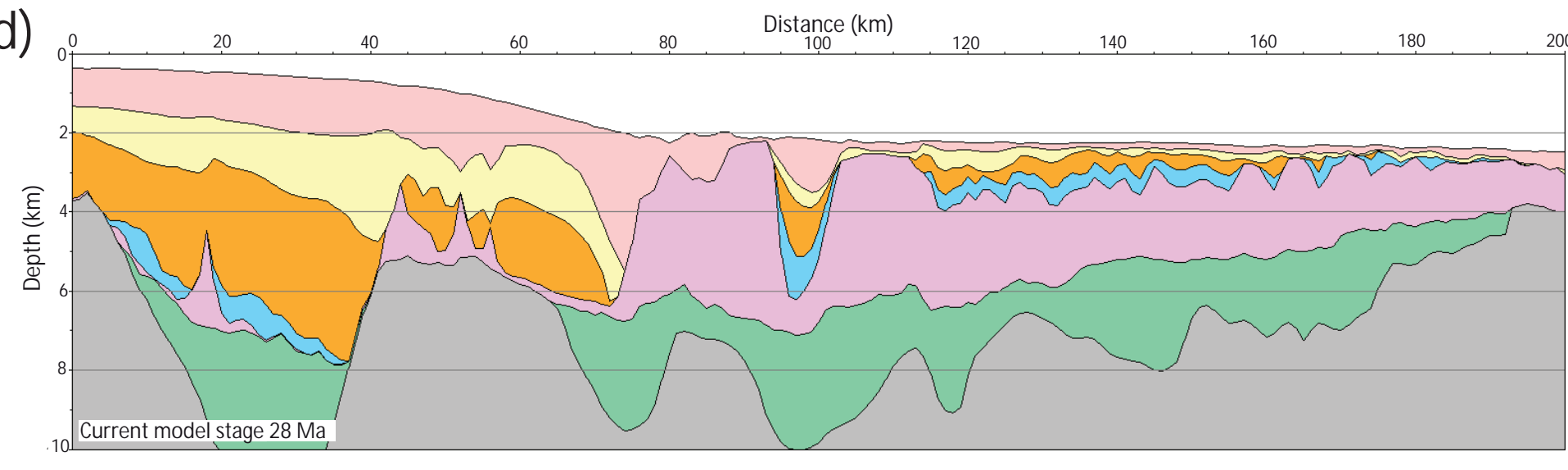

(f)

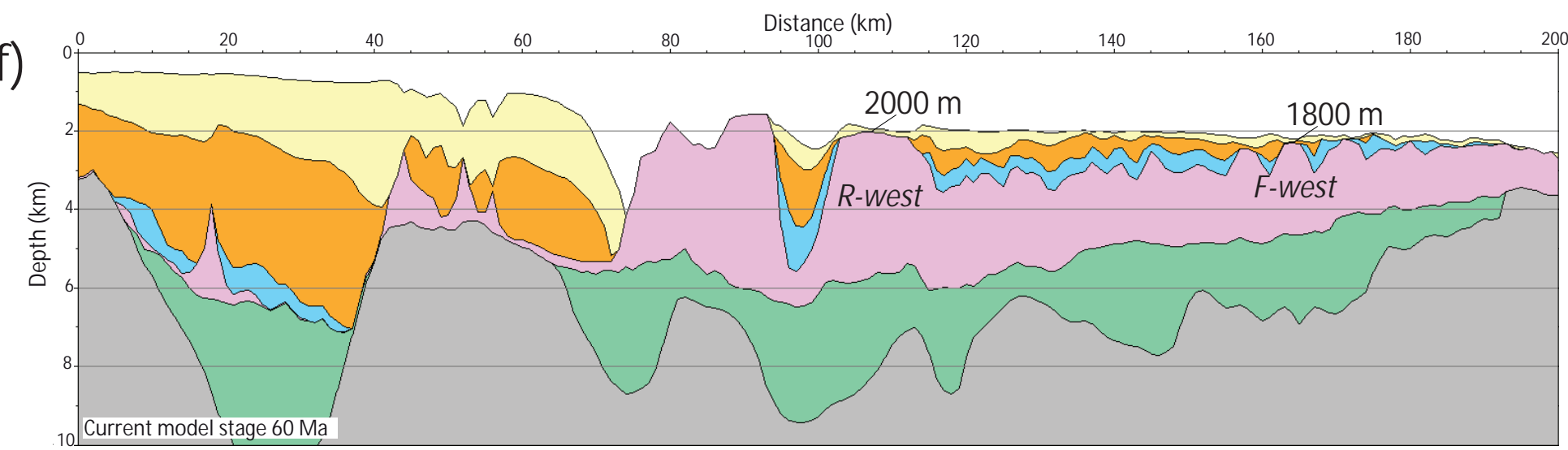

(C) $\stackrel{12}{2} \quad \frac{20}{\text { Maximum Beta stretching factor by }}$

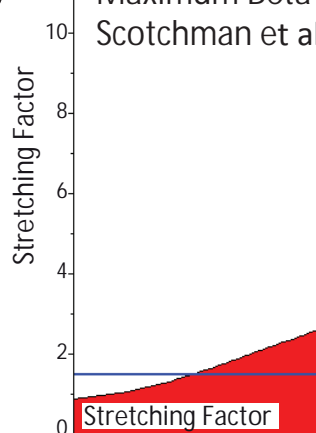

0 Stretching Factor (e)

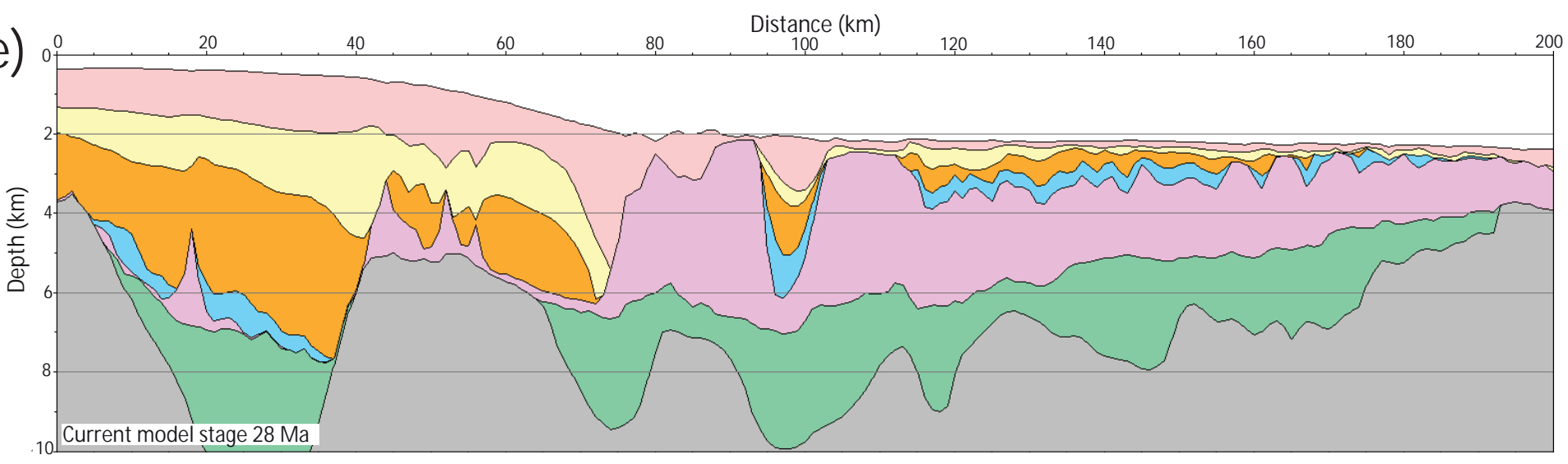

(g)

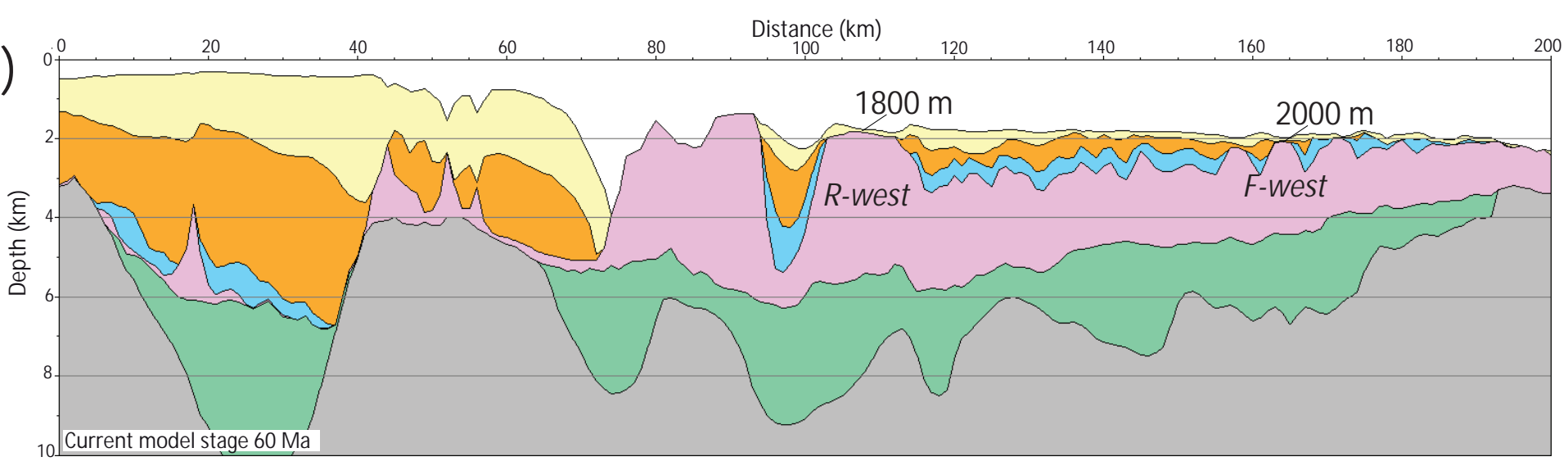



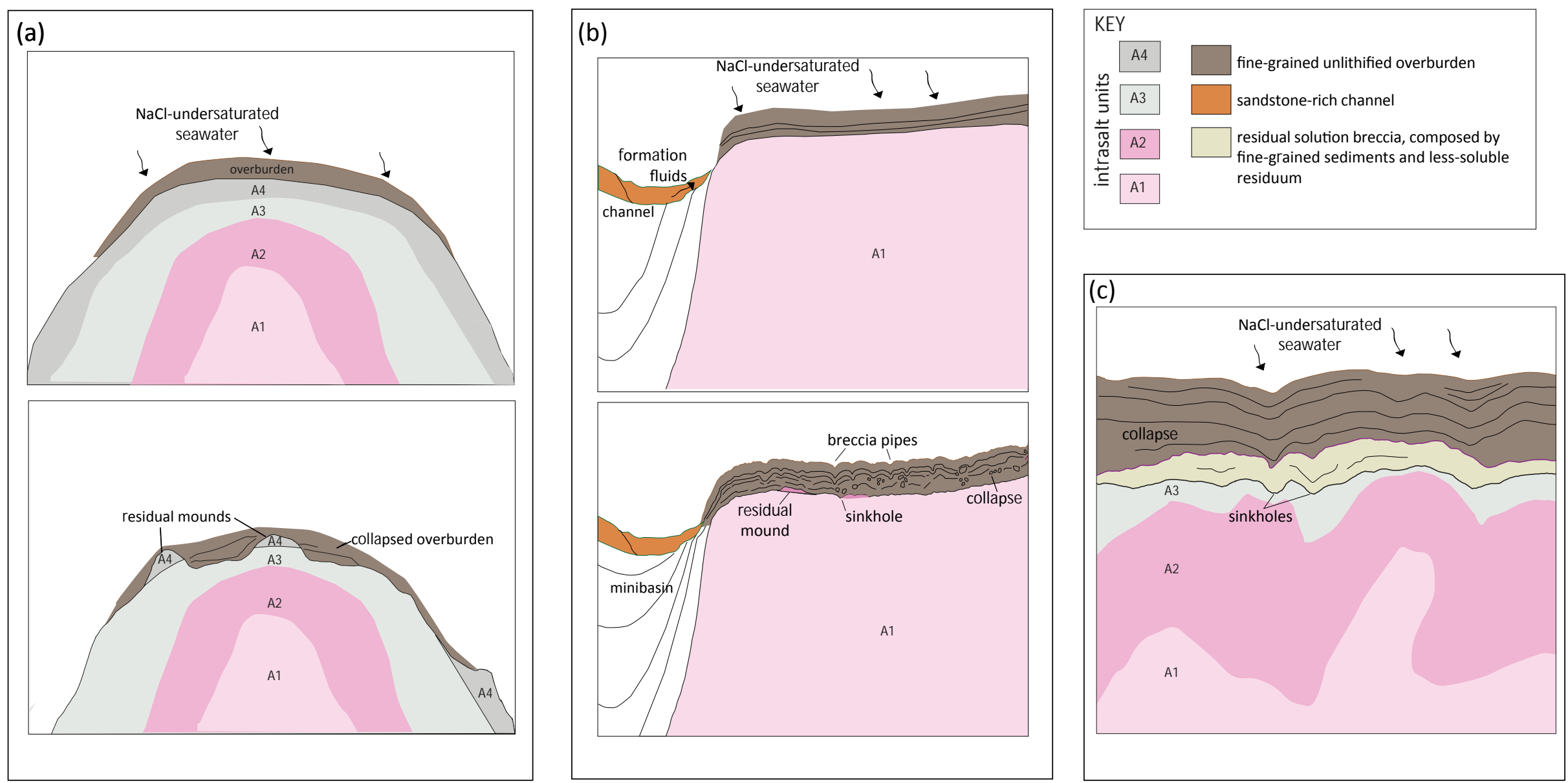

FIGURE 13: Mechanisms and styles of submarine salt dissolution: (a) Superjacent dissolution by NaCl-undersaturated seawater penetrating the very fine-grained, unlithified overburden during exposure at the seafloor; (b) Dissolution due to fluids migrating from carrier beds directly in contact with the salt; (c) Residual Solution breccia formed by the preferential depletion of the evaporite-dominated crests and collapse of the overburden. 